\title{
Cryopreservation for tree species with recalcitrant seeds: the avocado case
}

${ }^{1}$ C. O’Brien, ${ }^{1}$ J. Hiti-Bandaralage, ${ }^{2}$ R. Folgado, ${ }^{1}$ A. Hayward, ${ }^{2}$ S. Lahmeyer, ${ }^{2}$ J. Folsom and ${ }^{1}$ N. Mitter

${ }^{1}$ Centre for Horticultural Science, Queensland Alliance for Agriculture and Food Innovation, The University of Queensland, St Lucia, Queensland, 4072, Australia

2 The Huntington Library, Art Museum, and Botanical Gardens, 1151 Oxford Road, San Marino, CA 91108, USA

Contact: Chris O’Brien (c.obrien4@uq.edu.au)

\section{Abstract}

Recent developments in the cryopreservation space has increased the trend in germplasm collections established through cryopreserved in vitro material. Cryopreservation of recalcitrant seeds through embryos and embryonic axes, is not uncommon. Tropical and subtropical plants are not acclimated to the cold season, therefore have no in-built natural resilience to the cold. Also, larger seeds from trees, such as avocado (Persea americana Mill.), mango (Mangifera indica) and durian (Durio zibethinus L.) are sensitive to desiccation, chilling and freezing stress, making them unsuitable for seed banking or cryopreservation. Alternatively, as seeds do not carry the same genetic make-up as the mother plant, especially in the context of woody rainforest species of which the cross-pollination is dominant; seed conservation does not serve the purpose of germplasm preservation. Other plant material and methods are needed for these plants to be successfully stored in liquid nitrogen (LN). One such method commonly used is shoot-tip cryopreservation which ensures the clonal fidelity of germplasm. There are many problems when using shoot tips of tropical recalcitrant-seeded species. These include: 1) the toxic effects of cryoprotective agents towards structural integrity; 2) optimum developmental stage for success and 3) oxidative stress associated with excision injury leading to necrosis triggering cell death and hindering regeneration for the shoot tips in culture. A pre-requisite for any cryopreservation system is the availability of an established tissue culture regeneration platform. This review will outline conservation strategies for avocado with special emphasis on attempts and improvements made in the cryopreservation space for storing this horticulturally important crop 'avocado' at ultra-low temperatures. 


\section{Introduction}

Globally plants are recognized as a vital component of biodiversity and sustainability. An estimated 7000 species of plants provide food in the form of fibre, fuel, shelter, medicine [1]. Conservation and utilization of genetic resources requires many methods; however, the best results are often achieved when both traditional (in situ and ex situ conservation) and modern biotechnological tools (in vitro conservation and cryopreservation) are used in combination [2].

In situ conservation involves the designation, management and monitoring of target taxa where they are encountered [3]. It protects an endangered plant species in its natural habitat. It is especially appropriate for wild species and landrace material on farm [4]. In situ techniques are described as protected areas, e.g., genetic reserve, on-farm and home garden conservation. It is complementary to ex situ conservation particularly to conserve species that are difficult to conserve under ex situ conditions.

Ex situ conservation is advantageous as physical attributes and characteristics of the accessions such as plant habit, yield, tree height and disease resistance can be evaluated periodically [5]; however, there are several limitations posed; high maintenance cost, intensive labour and land requirements, pressure of natural calamities, risk of biotic and abiotic stresses as well as funding sources and economic decisions limiting the level of accession replication to maintain genetic diversity.

In vitro conservation is generally the maintenance of plant material under in vitro culture with growth retardants [6], reduced light [7] or reduced temperature [8] to achieve slow growth. Plant germplasm storage via these methods has been increased with more tissue culture protocols being developed for a vast number of plant species [9-11]. These methods allow for physiological evaluation of material and rapid multiplication and plant establishment when needed, still, very costly to maintain due to space, consumables and labour inputs.

Plant cryopreservation (storage at $-196 \pm 1{ }^{\circ} \mathrm{C}$ ) is a technique whereby plant tissues are preserved at ultra-low temperatures without losing viability [12]. A wide range of plant tissue can be cryopreserved, e.g., pollen, seeds, shoot tips, dormant buds, cell suspensions, embryonic cultures, somatic and zygotic embryos and callus tissue [13-14]. The choice of material used, depends on the conservation goal, e.g., seeds and embryos capture species diversity; whereas shoot tips and dormant buds capture specific genotypes [15]. Cryopreservation offers a 
continual supply of material for long-term in vitro research involving genetic manipulations [16] and often combined with tissue culture techniques [17].

Recent uses of cryopreservation including cryotherapy to eradicate pathogens, such as bacteria, phytoplasmas and viruses in plants [18-19] is gaining a lot of attention [16]. Samples are normally given a short exposure to LN and surviving cells are regenerated from meristematic tissue which is pathogen-free [19].

Theoretically, cryopreserved materials can be stored indefinitely without any genotypic and phenotypic variations [16], offering an attractive approach to conserve germplasm of both shoot tips and somatic embryos [17]. Cryopreservation is currently the only available alternative for long-term storage of recalcitrant-seeded species such as avocado $[12,20]$.

\section{Cryopreservation for plant species with recalcitrant seeds}

During the time conservation methods have been used for storing plant tissue, many reviews have been carried out to determine success [21-24] and standards established for managing cryopreservation gene banks [25-26]. Due to the success of in vitro conservation techniques, many in vitro gene banks have been established nationally and internationally [2728] with several cryopreservation germplasm repositories set-up for various plant species (Table 1).

Table 1 Some examples of germplasm repositories for various plant species.

\begin{tabular}{|l|l|}
\hline \multicolumn{1}{|c|}{ Germplasm Bank } & \multicolumn{1}{c|}{ Genus \& Accessions held } \\
\hline $\begin{array}{l}\text { France } \\
\text { - The International Network for the Improvement of } \\
\text { Banana and Plantain }\end{array}$ & Musa-882 [29] \\
- Institute of Research for Development & Coffea - approx. 500 [30] \\
\hline $\begin{array}{l}\text { Peru } \\
\text { - International Potato Centre }\end{array}$ & Solanaceae - approx. 755 [31] \\
\hline $\begin{array}{l}\text { Costa Rica } \\
\text { Centre for Research and Higher Learning in }\end{array}$ & Coffea - 80 [32] \\
\hline $\begin{array}{l}\text { Rep. Korea } \\
\text { National Institute of Crop Science, Rural }\end{array}$ & Solanaceae - approx. 1223 [30] \\
\hline Development Administration & \\
\hline
\end{tabular}




\begin{tabular}{|c|c|}
\hline $\begin{array}{l}\text { Japan } \\
\text { - National Centre for Seeds and Seedlings } \\
\text { - Shimane Agriculture Research Centre } \\
\text { - National Institute of Agrobiological Sciences }\end{array}$ & $\begin{array}{l}\text { Solanaceae }-130[30] \\
\text { Wasabi }-40[30] \\
\text { Mulberry }- \text { approx. 1000; } \\
\text { Juncus - } 50[30]\end{array}$ \\
\hline $\begin{array}{l}\text { Germany } \\
\text { - Leibniz Institute of Plant Genetics and Crop Plant } \\
\text { Research }\end{array}$ & $\begin{array}{l}\text { Solanaceae }-2885 \\
\text { Mint }-97 \\
\text { Allium - } 112[30,33]\end{array}$ \\
\hline $\begin{array}{l}\text { India } \\
\text { - Potato Research Institute, Shimla } \\
\text { - National Bureau of Plant Genetic Resources, New } \\
\text { Delhi }\end{array}$ & $\begin{array}{l}\text { Solanaceae - } 1500[30,34] \\
\text { Legumes - } 67274[35]\end{array}$ \\
\hline $\begin{aligned} & \text { USA } \\
& \text { - National Clonal Germplasm Repository }\end{aligned}$ & $\begin{array}{l}\text { Malus }-6073 \\
\text { Pyrus }-131 \\
\text { Rubus }-57 \\
\text { Vitis }-1405 \text { [36-37] }\end{array}$ \\
\hline
\end{tabular}

Cryopreservation is a safe and cost-effective option for long-term conservation of genetic resources of non-orthodox or recalcitrant seeded species [38] with seeds that cannot be stored long-term. A considerable number of species, mostly sub-tropical or tropical in origin have recalcitrant seeds, e.g., coconut, cacao, mango, avocado and many fruit and forest tree species [39-40]. These recalcitrant seeds are shed at relatively high moisture content, thus cannot undergo drying to facilitate long-term storage [4, 41]. The heterogenous nature of seeds produced through open pollination limits effectiveness of and aim of conservation [4, 42]. Over almost 100 different species of zygotic embryos/embryonic axes and somatic embryos of approximately 40 different species, from both tropical and temperate climates, consisting of fruit, forest trees, and crops with seeds of intermediate, orthodox and recalcitrant storage characteristics, have been successfully cryopreserved [16].

Many cryopreservation techniques/protocols have been developed for storing germplasm of various plant material e.g. seeds, pollen, somatic embryos, dormant buds and shoot tips [38, 43]. Plants cryopreserved using callus (unorganized) can be susceptible to 
genetic variation when regenerated [44]. Shoot tip cryopreservation is advantageous as it is clonal and true to the accession being preserved without any heterogeneity. Apical meristems, the most commonly used, are at less risk of genetic variations due to their organised structure. Meristems are made up of small unvacuolated cells generally having a small vascular system [44]. The earliest plant species studied for shoot-tip cryopreservation were potato (Solanaceae spp.) and cassava (Manihot esculenta) [45]. The early protocols used controlled-rate cooling, these were later refined to improve all steps of the protocols and applied to many plants, especially temperate species [46-47].

Shoot-tip cryopreservation protocols, developed following procedures for plant-cell suspensions [31], included the use of controlled-rate cooling (two-step cooling procedures) to freeze water in the intracellular spaces and dehydrate cells to the point where they would turn to a glassy state (vitrify) upon contact with LN [15, 48-49]. Rapid cooling usually results in intracellular ice formation, whereas slow cooling results in extracellular ice formation [50] responsible for osmotic shock injury [12]. The formation of intracellular ice damages cell membranes directly as the growing ice crystals push apart and rupture membranes causing cell damage [51]. Cryoprotectants are generally used in vitrification protocols; they are a chemical substance or mixture generally high in molarity that prevents intracellular ice formation, or prevents damage to cells during cooling [12, 52-53]. Cryopreservation has several steps: 1) initial excision of the germplasm; 2) desiccation or pre-culture on osmotic media to reduce water content; 3) cryoprotection through exposure to cryoprotective agents; 4) cryopreservation in LN; 5) re-warming; and 6) unloading of cryoprotective agents and recovery of germplasm after cryopreservation [20].

\subsection{Cryopreservation methods to reduce water content}

Concentrated intracellular solute is a pre-requisite for successful cryopreservation and can be achieved with the following methods (Table 2), either individually or in combination [54-57]. 
Table 2 Methods to dehydrate/concentrate intracellular solute for cryopreservation.

\begin{tabular}{|c|c|}
\hline Dehydration Method & Uses \\
\hline - Desiccation & $\begin{array}{l}\text { - Air drying of explants in laminar flow hood or using flow } \\
\text { of compressed air. } \\
\text { - } \quad \text { Dehydration of explants in a desiccator with silica gel. }\end{array}$ \\
\hline $\begin{array}{l}\text { Cryoprotectants/ } \\
\text { vitrification } \\
\text { solutions }\end{array}$ & $\begin{array}{l}\text { - Penetrating cryoprotectants, e.g., dimethyl sulfoxide } \\
\text { (DMSO) and glycerol have rapid penetrating power and act } \\
\text { by replacing intracellular water. } \\
\text { - Non-penetrating cryoprotectants, e.g., sucrose, } \\
\text { polyvinylpyrrolidone (PVP) and polyethylene glycol } \\
\text { (PEG), dehydrate cells by exerting osmotic stress. } \\
\text { - Commonly used cryoprotectant mixes are plant vitrification } \\
\text { solution } 2 \text { (PVS2) [58] and plant vitrification solution } 3 \\
\text { (PVS3) [59]. }\end{array}$ \\
\hline $\begin{array}{l}\text { Freeze-induced } \\
\text { dehydration }\end{array}$ & $\begin{array}{l}\text { - Preferential freezing of extracellular water by slow cooling } \\
\text { at a rate of } 0.5-2{ }^{\circ} \mathrm{C} \text { per min creates a hypotonic } \\
\text { surrounding for the cell, resulting in outflow of cellular } \\
\text { water. }\end{array}$ \\
\hline $\begin{array}{l}\text { Pre-conditioning } \\
\text { of donor plant or } \\
\text { explant }\end{array}$ & $\begin{array}{l}\text { - Including DMSO, abscisic acid, sucrose, polyols or proline } \\
\text { in the pre-culture medium or low temperature treatment to } \\
\text { induce tolerance to dehydration and freezing. }\end{array}$ \\
\hline
\end{tabular}

Cryopreservation protocols using vitrification solutions typically involve a two-step cryoprotection process: (1) loading by incubation in loading solution; and (2) dehydration using vitrification solution [56]. Loading solutions are commonly used to improve permeation of the cryoprotectant through cell membrane, it also induces tolerance to dehydration, which will be imposed by vitrification solutions. A common loading solution used is $2 \mathrm{M}$ glycerol $+0.4 \mathrm{M}$ sucrose [56]. Vitrification solutions contain chemicals that are high in concentration, e.g., ethylene glycol, glycerol and DMSO which have been reported as toxic to plant tissue [60]. It is therefore important to establish minimum exposure time to vitrification solutions in order to dehydrate tissue sufficiently to undergo cryopreservation and avoid damage effects to plant tissue [61-62]. 
Application of cryoprotectants is the most widely used method in cryopreservation protocols. Cryoprotectants are mainly classified into two categories: penetrating and nonpenetrating [63]. Penetrating cryoprotectants pass through the plasma-membrane to equilibrate between extracellular solution and the cell interior [15]. Whereas non-penetrating cryoprotectants do not pass through the plasma membrane and accumulate in the extracellular solution [15]. Cryoprotectants that are penetrating in nature are able to reduce cell water at temperatures sufficiently low to minimize the damaging effect of the concentrated solutes on the cells [63]. Whereas non-penetrating cryoprotectants osmotically "squeeze" water from the cells during the initial phases of freezing at temperatures between -10 and $-20{ }^{\circ} \mathrm{C}$ [63]. Cryoprotectants that are penetrating in nature are mainly comprised of DMSO, glycerol and amino acids [54] e.g., mixtures of DMSO and glycerol [58]. Non-penetrating cryoprotectants include various types of sugars, high molecular weight additives like PEG and alcohols [54]. Penetrating substances like, DMSO, are often preferred as cryoprotectants due to its ability to enter the cells rapidly, however, DMSO is considered as toxic to plant cells and often glycerol and sugar are substituted [54].

Many authors have developed mixtures of cryoprotectants since the discovery of their benefits in protecting cells during the cryogenic process [58-60, 64-65]. The most commonly used cryoprotectant for plant cells is PVS2 [58] and PVS3 [59]. Plants can be pre-treated with sucrose $[60,62,66-67]$ to help acquire dehydration tolerance, thus usually enhancing survival after cryopreservation when applied with vitrification solution. Pre-culture is achieved by incubating shoot tips in high sugar containing media (usually by daily increasing concentration of sugar) causing dehydration [68]. Another method to improve tolerance to vitrification solutions is cold hardening in which the donor plants are exposed to a lower temperature usually around $4{ }^{\circ} \mathrm{C}$ [69-72].

Table 3 Some examples of cryoprotectants used for plant tissue.

\begin{tabular}{|l|l|}
\hline Cryoprotectant & \multicolumn{1}{|c|}{ Composition } \\
\hline PVS1 & \begin{tabular}{l}
$30 \%$ w/v glycerol, 15\% w/v EG, 5\% w/v sucrose, 15\% w/v DMSO [65] \\
\hline PVS2
\end{tabular} \\
& $\begin{array}{l}30 \%(\mathrm{w} / \mathrm{v}) \text { glycerol, 15 \% (w/v) DMSO, 15 \% (w/v) EG, and 15 \% } \\
\text { sucrose [58] }\end{array}$ \\
\hline PVS3 & $50 \%(\mathrm{w} / \mathrm{v})$ glycerol and 50 \% (w/v) sucrose [59] \\
\hline PVS4 & $35 \%(\mathrm{w} / \mathrm{v})$ glycerol, 20 \% (w/v) EG, and 20.5\% M sucrose [73] \\
\hline
\end{tabular}




\begin{tabular}{|l|l|}
\hline VSL+ & $\begin{array}{l}20 \%(\mathrm{w} / \mathrm{v}) \text { glycerol, } 10 \%(\mathrm{w} / \mathrm{v}) \mathrm{DMSO}, 30 \%(\mathrm{w} / \mathrm{v}) \mathrm{EG}, 15 \% \text { sucrose } \\
\text { and } 10 \mathrm{mM} \mathrm{CaCl}_{2}[74]\end{array}$ \\
\hline VSL & $\begin{array}{l}20 \%(\mathrm{w} / \mathrm{v}) \mathrm{glycerol}, 10 \%(\mathrm{w} / \mathrm{v}) \mathrm{DMSO}, 30 \%(\mathrm{w} / \mathrm{v}) \mathrm{EG}, 5 \% \text { sucrose and } \\
10 \mathrm{mM} \mathrm{CaCl} 2[74]\end{array}$ \\
\hline Steponkus & $\begin{array}{l}50 \%(\mathrm{w} / \mathrm{v}) \mathrm{EG}, 15 \% \text { sorbitol, } 6.0 \% \text { bovine serum albumin, } 13.7 \% \\
\text { sucrose [75] }\end{array}$ \\
\hline Towill & $35 \% \mathrm{EG}, 6.8 \%(\mathrm{w} / \mathrm{v})$ DMSO, $10 \%$ PEG 8000, and 13.7\% sucrose [76] \\
\hline Fahy & $20 \% \mathrm{DMSO}, 20 \%$ formamide, $15 \%$ propylene glycol [77] \\
\hline
\end{tabular}

\subsection{Cryopreservation techniques}

Presently there is no one method of cryopreservation that can be applied to a diverse range of plant species. Many cryopreservation techniques (Table 4) have been developed for shoot tips and somatic embryos depending on the plant species used. Many cryopreservation techniques have been identified [9]; namely, vitrification, droplet-vitrification, encapsulationvitrification, encapsulation-dehydration, dehydration, pre-growth, pre-growth-dehydration and the $\mathrm{D}$ and $\mathrm{V}$ plate method, a modification of the encapsulation-vitrification and dropletvitrification [56, 78-79].

Table 4 Some examples of cryopreservation techniques and applications used.

\begin{tabular}{|l|l|}
\hline \multicolumn{1}{|c|}{ Technique } & \multicolumn{1}{|c|}{ Application } \\
\hline $\begin{array}{l}\text { Vitrification. Pre-culture of cultures on basal } \\
\text { medium supplemented with cryoprotectants, } \\
\text { pre-treatment with loading solution, } \\
\text { dehydration with PVS, rapid freezing and } \\
\text { thawing. }\end{array}$ & $\begin{array}{l}\text { Cocoa somatic embryos showed a 74 \% } \\
\text { survival rate with PVS2 treatment for 1 } \\
\text { h at 0 }{ }^{\circ} \mathrm{C} \text { [80]. }\end{array}$ \\
\hline $\begin{array}{l}\text { Droplet-vitrification. Explants are placed } \\
\text { individually in a droplet of PVS placed on } \\
\text { alfoil strip and then placed in a cryo tube } \\
\text { before immersion in LN. }\end{array}$ & $\begin{array}{l}\text { Table, vineyard and rootstock grapes } \\
{[17,81-85] . \text { Wild grape germplasm [17, }} \\
86] . \quad \text { Sugar-cane somatic embryos } \\
\text { achieved 55 \% viability [87]. Avocado } \\
\text { embryogenic cultures with 77 - 100 \% } \\
\text { recovery [88]. }\end{array}$ \\
\hline $\begin{array}{l}\text { Encapsulation-vitrification. Sodium } \\
\text { alginate beads are formed and explants are }\end{array}$ & $\begin{array}{l}\text { Olea europaea (olive) somatic embryos } \\
\text { showed 64\% regrowth after 4-day pre- }\end{array}$ \\
\hline
\end{tabular}




\begin{tabular}{|c|c|}
\hline $\begin{array}{l}\text { encapsulated in them and dehydrated in PVS } \\
\text { before freezing. }\end{array}$ & $\begin{array}{l}\text { culture in sucrose, PVS2 treatment for } 3 \\
\text { hr treatment and rapid freezing [89]. }\end{array}$ \\
\hline $\begin{array}{l}\text { Encapsulation-dehydration. } \\
\text { alginate-encapsulated cultures } \\
\text { dehydrated osmotically with high } \\
\text { concentrations of sucrose for } 1-7 \text { days } \\
\text { or/and desiccated in an air current before } \\
\text { slow cooling to }-80{ }^{\circ} \mathrm{C} \text { and then immersed in } \\
\text { LN. }\end{array}$ & $\begin{array}{l}40 \% \text { regrowth of olive somatic embryos } \\
\text { was achieved following } 4 \text { days of } \\
\text { sucrose pre-growth, desiccation and } \\
\text { freezing [89]. Prunus armeniaca shoots } \\
\text { were recovered after being treated with } \\
0.5 \mathrm{M} \text { sucrose for } 2 \text { days followed by air } \\
\text { dehydration for } 2 \text { hr and frozen in LN } \\
\text { [90]. Vitis spp. optimal survival of } 60 \\
\text { and } 40 \% \text { for cultivars LN33 hybrid and } \\
\text { Superior was achieved when } \\
\text { encapsulated shoots were dehydrated to } \\
15.6 \text { and } 17.6 \% \text { water content } \\
\text { respectively [91]. }\end{array}$ \\
\hline $\begin{array}{l}\text { Dehydration. Samples are dehydrated by } \\
\text { either air current, silica gels, or incubation } \\
\text { with cryoprotectant, followed by rapid } \\
\text { freezing or two-step freezing. }\end{array}$ & $\begin{array}{l}\text { This technique gave good recovery with } \\
\text { embryos of desiccation-tolerant species } \\
\text { such as conifers, melon, Brassica and } \\
\text { Picea [16]. Avocado somatic embryos } \\
\text { showed } 80 \% \text { recovery in one } \\
\text { embryogenic line using DMSO as } \\
\text { cryoprotectant [88]. }\end{array}$ \\
\hline $\begin{array}{l}\text { Pre-growth and pre-growth-dehydration. } \\
\text { Samples are cultured on media containing } \\
\text { cryoprotectants such as DMSO, dehydrated } \\
\text { and then frozen slowly or rapidly. }\end{array}$ & $\begin{array}{l}\text { Elaeis guineensis (oil palm) somatic } \\
\text { embryos required } 7 \text { days of pre- } \\
\text { treatment before desiccation [92] } \\
\text { whereas coffee embryos required a 2- } \\
\text { week treatment [93], and citrus embryos } \\
\text { only } 1 \text { day [94]. }\end{array}$ \\
\hline $\begin{array}{l}\text { D and V-plate method. } \\
\text { Is a modification of the encapsulation- } \\
\text { vitrification and droplet-vitrification } \\
\text { technique. }\end{array}$ & $\begin{array}{l}\text { With the V cryo-plate method, high } \\
\text { regrowth was obtained in Solanum } \\
\text { tuberosum (potato) (average } 99 \%, 17 \\
\text { lines), Saccharum officinarum } \\
\text { (sugarcane) (average } 70 \%, 12 \text { lines), }\end{array}$ \\
\hline
\end{tabular}




\begin{tabular}{|c|c|}
\hline $\begin{array}{l}\text { For the V cryo-plate method, dehydration is } \\
\text { performed using the vitrification solution } \\
\text { PVS2, while in the D cryo-plate method, } \\
\text { dehydration is achieved using the air current } \\
\text { of the laminar flow cabinet or silica gel [95]. }\end{array}$ & $\begin{array}{l}\text { Fragaria spp. (strawberry) (average } \\
81 \%, 15 \text { lines), Mentha spp. (mint) } \\
\text { (average } 89 \%, 17 \text { lines) and Morus alba } \\
\text { (mulberry) (average } 87 \%, 13 \text { lines) [95]. } \\
\text { With the D cryo-plate method, high } \\
\text { regrowth levels were obtained in Juncus } \\
\text { spp. (mat rush) (average 86\%, } 20 \text { lines), } \\
\text { Tanacetum cinerariifolium } \\
\text { (chrysanthemum) (average 88\%, } 7 \\
\text { lines), Diospyros kaki (persimmon) } \\
\text { (average } 87 \%, 10 \text { lines), and Vaccinium } \\
\text { corymbosum L. blueberry (average } 80 \%, \\
\text { 10 lines) [95]. }\end{array}$ \\
\hline
\end{tabular}

\subsubsection{Vitrification}

Vitrification technique can include the pre-culture of samples on medium supplemented with sucrose, then treated with a loading solution normally high in sucrose molarity [56] (e.g., a mixture of sucrose and glycerol), dehydration with a vitrification solution such as PVS2 or PVS3, rapid freezing, thawing, and plant recovery by removing cryoprotectants [96].

\subsubsection{Droplet-vitrification}

The droplet-vitrification technique is a modification of the vitrification technique [97]; treating explants with loading (usually $2 \mathrm{M}$ glycerol and $0.4 \mathrm{M}$ sucrose) and vitrification solutions; freezing them ultra-rapidly in a droplet of vitrification solution either PVS2 or PVS3 placed on an alfoil strip [98] with a droplet of cryoprotectant added before immersion in LN. The alfoil strip helps with the ultra-rapid cooling (about $4000-5000{ }^{\circ} \mathrm{C} \mathrm{min}^{-1}$ ) and re-warming $\left(3000-4500{ }^{\circ} \mathrm{C} \mathrm{min}^{-1}\right)$ of samples due to the good conductivity of thermal current of aluminium [99]. The removal of the cryoprotectant is achieved during re-warming stage by using an unloading solution usually with high level of sucrose $1.2 \mathrm{M}$, then transferred to recovery and regeneration media $[13,61]$. The droplet vitrification protocol combines the use of highly concentrated vitrification solutions with ultra-fast cooling and re-warming rates [100] shown to be critical for survival [101]. For high success in survival and recovery of shoot tips after LN it is vital that samples are sufficiently dehydrated by the vitrification solution in order to vitrify while rapidly cooling in $\mathrm{LN}$ [70]. 


\subsubsection{Encapsulation-vitrification and encapsulation-dehydration}

These two techniques have been successfully applied to cryopreserve shoot tips of woody species of crops, such as, Malus [102-103], Pyrus, Morus [102], Vitis [91] and Poncirus trifoliata $\times$ Citrus sinensis [104-105]. Dissected shoot tips or somatic embryos are suspended in a solution of sodium alginate. Beads (4-5 mm in size) are then formed using a truncated pipette tip and pipetting into a solution of $\mathrm{CaCl}_{2}$ where they are allowed to set for $30 \mathrm{~min}$ [56]. For encapsulation-vitrification, once beads are formed with explant inside, they are then dehydrated in PVS solutions such as PVS2 or PVS3 prior to immersion in LN. Although encapsulation is time-consuming, it eases manipulation due to alginate beads being relatively large in size [56]. For the encapsulation-dehydration technique instead of dehydration with PVS solutions beads are dehydrated in a laminar flow hood or under silica gel before immersion in $\mathrm{LN}[56]$.

\subsubsection{Dehydration}

Of all the techniques explained, dehydration technique is the simplest procedure, as it involves just the dehydration of explants followed by direct immersion in LN. Embryonic axes or zygotic embryos extracted from seeds are mainly used for this technique. It produces good results with embryos that are of desiccation-tolerant species such as melon, Brassica and conifers [16]. Desiccation is usually achieved by the air current of a laminar airflow cabinet or over silica gel. Dehydration using a vitrification solution removes intracellular water from cells and permits intracellular solution to undergo phase transition from liquid phase into an amorphous phase upon rapid cooling [56]. Cryoprotectant mixtures are commonly used as vitrification solution, such as PVS2 and PVS3.

\subsubsection{Pre-growth and pre-growth-dehydration}

In the pre-growth and pre-growth-dehydration technique, explants are first exposed and grown on media containing cryoprotectants, dehydrated by air under a laminar flow cabinet or with silica gel, and then frozen rapidly. Depending on the plant species optimal conditions can vary greatly.

\subsubsection{D and V-plate method}

Both methods use special aluminium cryo-plates which have been developed (length $37 \mathrm{~mm}$, width $7 \mathrm{~mm}$ and a thickness of $0.5 \mathrm{~mm}$ with 10 wells). An alginate solution containing $2 \%(\mathrm{w} / \mathrm{v})$ sodium alginate in calcium-free MS basal medium with $0.4 \mathrm{M}$ sucrose is poured over the cryo -plate. Samples are placed in wells and more sodium alginate solution is poured over 
the top to cover them. In the $\mathrm{V}$ cryo-plate method, dehydration is performed using the vitrification solution PVS2, while in the D cryo-plate method, dehydration is achieved using the air current of the laminar flow cabinet or silica gel [95]. After dehydration cryo-plates are immersed in LN. The main advantages of the V and D cryo-plate methods is that handling of specimens throughout the procedure is easy and quick because only the cryo-plates are manipulated [95].

\section{The avocado case}

\subsection{Background}

Avocado (Persea americana Mill.), a high-value fruit native found in tropical and subtropical regions of America belongs to the family Lauraceae, genus Persea [106]. It is a grafted crop and often cultivars for scions and rootstocks are chosen for important agronomical traits based on the growing region [107]. In Australia, avocados are produced almost all year round due to the vast range of climates and conditions in our eight major avocado growing regions [108]. The cultivar, 'Hass', represents $81 \%$ of total production [108] with 2018/19 producing 85546 tonnes of avocados, an $11 \%$ increase on the previous season's 77032 tonnes [108]. Consumer market value of Australian fruit sold domestically was worth $\$ 898 \mathrm{~m}$ [108]. Increased consumer demand is due to its popularity as a healthy eating alternative; often referred to as a superfood due to its beneficial nutrients, vitamins, minerals, fibre and healthy fats [109-110].

The main avocado sold throughout the world, 'Hass' is reported to be $61 \%$ Mexican and $39 \%$ Guatemalan [111]. Most of the new cultivars developed are 'Hass' doppelgangers such as 'Gem', 'Lamb Hass', 'Carmen' and 'Maluma' [112]. Many breeding programs have concentrated on the development of new rootstocks such as 'Dusa', 'Bounty' and 'Velvick' [113] to help the industry overcome abiotic threats and improve productivity.

\subsection{Diversity of avocado}

The diversity within the Persea genera can serve as a resource in crop improvement [114-116]; with approximately 90 species in tropical to sub-tropical America and the remaining species mostly distributed in the tropics to sub-tropics of Asia [106]. There are three recognised races of P. americana [117] with distinctive characteristics; e.g., plant habit, leaf chemistry, peel texture, fruit colour, disease and salinity tolerance [118]. The Mexican race, P. americana var. drymifolia is adapted to the tropical highlands; the Guatemalan race, P. americana var. guatemalensis is adapted to medium elevations in the tropics; and the West Indian race, $P$. 
americana var. americana is adapted to the lowland humid tropics [119]. Yet, there are at least 3 additional races suggested to exist $[117,120-121]$. The ability of the three main races to withstand cold conditions varies; the West Indian race cannot tolerate temperatures below 15 ${ }^{\circ} \mathrm{C}$, the Guatemalan race can tolerate cooler temperatures of -3 to $-1{ }^{\circ} \mathrm{C}$, and the Mexican race withstands temperatures as low as $-7{ }^{\circ} \mathrm{C}$ exhibiting the highest cold tolerance [122-124]. Cultivars classified as pure Guatemalan and Mexican races and Mexican $\times$ Guatemalan hybrids have been shown to have more diversity than those of pure West Indian race and Guatemalan $\times$ West Indian hybrid cultivars [115]. The Guatemalan and Mexican races and their hybrids are very important for conservation and future breeding programs [115].

New cultivars are normally derived from chance seedlings or mutations due to the difficult nature of breeding programs, which are costly, time-consuming and under threat of abiotic and biotic stresses. The threat of Ambrosia beetle species and its symbiont fungus Laurel Wilt disease to the avocado field gene banks and commercial industry in Florida, California, and Israel is a glaring example of an abiotic stress that could destroy the industry [112]. In Australia the bushfires in 2019/2020 have seen natural forests, bushlands and genetic diversity lost. Many Persea spp. grow in these forest areas [120]. It has been estimated that we have already lost around $40 \%$ of the forest cover in developing countries of the world through deforestation [125-126]. This has led to a loss of the genetic footprint of Persea spp. that has eroded potential useful genes for future breeding programs. This is devastating from a plant breeder's point of view, as the potential for new cultivar and rootstock development has been narrowed [125]. Also, genetic diversity plays an important role both ecologically and culturally.

Clonal rootstock propagation is a crucial step in avocado propagation. However, a problem exists in rootstocks with heavy reliance on seedling rootstocks due to several reasons 1) the long process needed to develop clonal rootstocks, 2) the price to produce clonal rootstocks and 3) difficulty in rooting mature cuttings of avocado [127], meaning the preferred choice is often seedling rootstocks. These rootstocks need to have good attributes, such as, salinity and resistance to diseases, e.g., Phytophthora cinnamomi, to be considered useful for avocado growers. An example of wild Persea spp. which can be taken advantage of is Persea steyermarkii, which grows adventitious roots from the main trunk when it is damaged [125] making it a dominant species in a forest in Chiapas and Mexico [128]. In Spain, a fungus called Rosellina necatrix is problematic, however, seedlings from the germplasm bank of the 
Fundación Salvador Sanchez Colin have shown a tolerance to this disease [129] with a potential to select accessions to combat the fungus.

\subsection{Avocado conservation}

\subsubsection{Ex situ conservation - Global germplasm repositories}

Avocado is an open-pollinated plant producing genetically different progeny of seeds, forcing germplasm to be conserved in field repositories (Table 5) instead of seed banking as the seeds are highly heterozygous and recalcitrant [130-131]. These field repositories (Fig. 1) are maintained at a high cost and are at risk, due to natural calamities; pest and disease threats.

Table 5 Germplasm sites throughout the world and avocado accessions held.

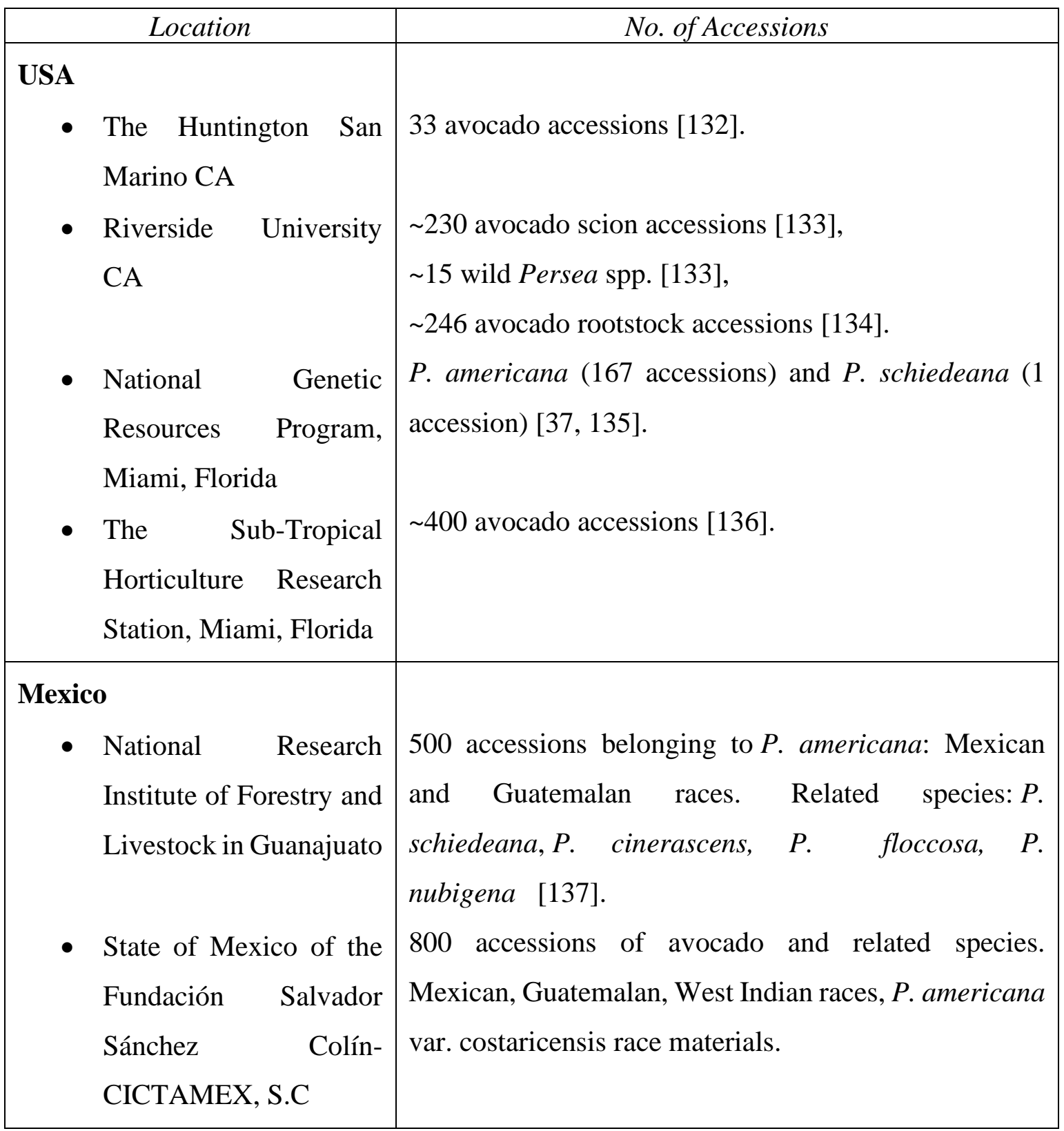




\begin{tabular}{|c|c|}
\hline $\begin{array}{l}\text { - Coatepec Harinas and } \\
\text { Temascaltepec, State of } \\
\text { Mexico, Mexico }\end{array}$ & $\begin{array}{l}\text { Wild relatives: Beilschmiedia anay, } B . \text { miersii, } P . \\
\text { schiedeana, P. longipes, } P \text {. cinerascens, } P \text {. hintonni, } P \text {. } \\
\text { floccosa, } P \text {. tolimanensis, } P \text {. steyermarkii, } P \text {. nubigena, } \\
P . \text { lingue, } P . \text { donnell-smithii, } P . \text { parvifolia, } P . \\
\text { chamissonis, Persea spp. }[137] .\end{array}$ \\
\hline $\begin{array}{l}\text { Ghana } \\
\text { University of Ghana Forest and } \\
\text { Horticultural Crops Research } \\
\text { Centre }\end{array}$ & $\begin{array}{l}110 \text { local landraces and } 5 \text { varieties from South Africa } \\
\text { ('Hass', 'Fuerte', 'Ryan', 'Ettinger' and 'Nabal') [138]. }\end{array}$ \\
\hline $\begin{array}{l}\text { Israel } \\
\text { Volcanic Centre in Bet Dagan }\end{array}$ & 194 trees, propagated from 148 accessions [139]. \\
\hline $\begin{array}{l}\text { Spain } \\
\text { The Experimental Station "La } \\
\text { Mayora" in Malaga }\end{array}$ & 75 avocado accessions $[136,140]$. \\
\hline Cuba & 210 genotypes [136]. \\
\hline Chile & $\begin{array}{l}4 \text { botanical breeds of } P \text {. americana: var. drymifolia, var. } \\
\text { guatemalensis, var. jacket and var. costaricencis [136]. }\end{array}$ \\
\hline $\begin{array}{l}\text { Australia } \\
\begin{aligned} \text { - } & \text { Maroochydore } \\
& \text { Research Station }\end{aligned}\end{array}$ & A small collection of 46 avocado accessions [141-142]. \\
\hline Nigeria & 8 avocado accessions [143]. \\
\hline $\begin{array}{l}\text { Brazil } \\
\text { - Brasilia, in the Federal } \\
\text { District, depending on } \\
\text { the Embrapa Research } \\
\text { Institute } \\
\text { - Conceição do Almeida } \\
\text { and Juazeiro } \\
\text { collections, both in the } \\
\text { Bahia State }\end{array}$ & $\begin{array}{l}30 \text { avocado accessions [144]. } \\
22 \text { avocado accessions [144]. }\end{array}$ \\
\hline
\end{tabular}




\begin{tabular}{|l|l|}
\hline $\begin{array}{l}\text { Piracicaba, in the São } \\
\text { Paulo State }\end{array}$ & 7 avocado accessions [144]. \\
- Jaboticabal, in the São \\
Paulo State
\end{tabular}

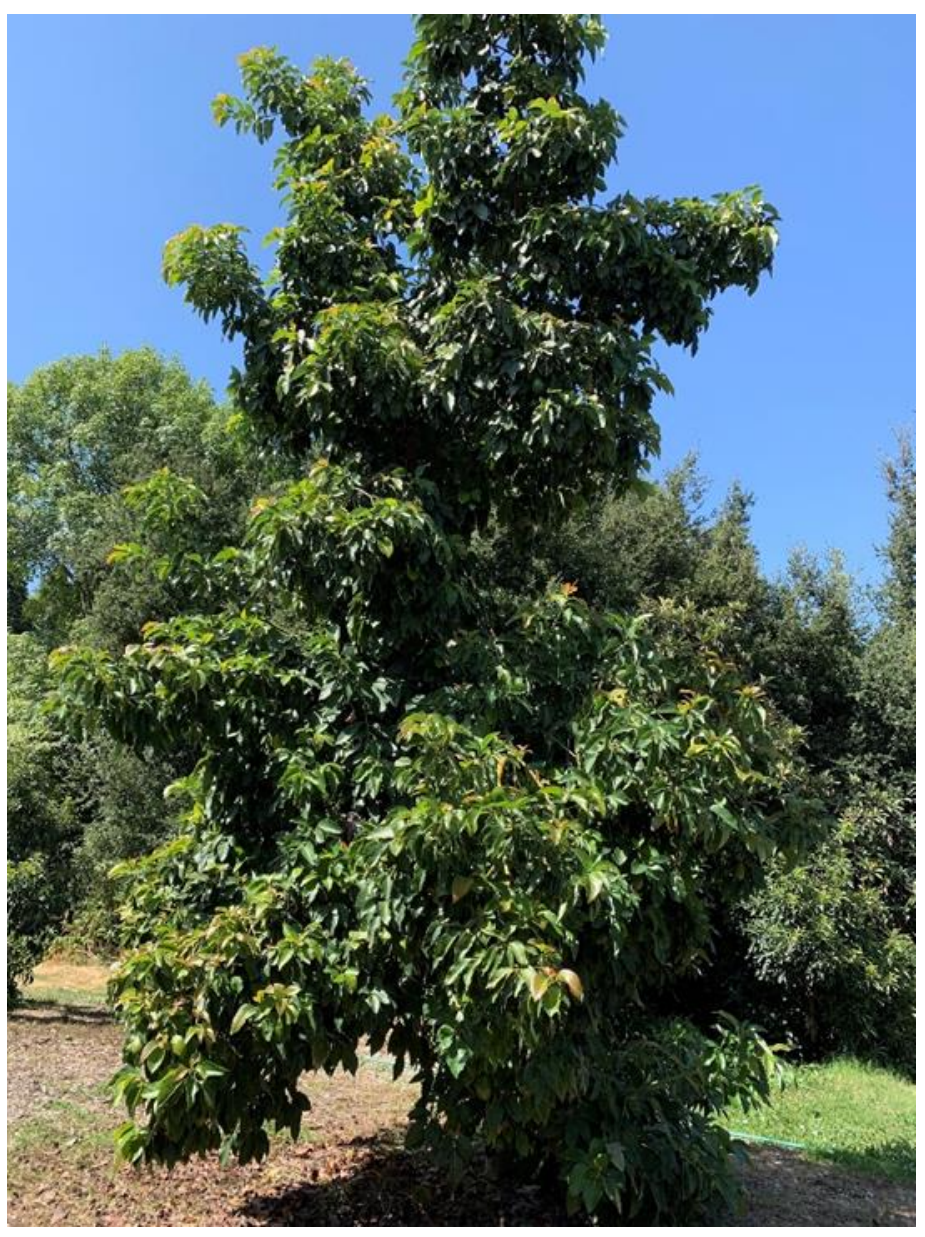

Fig. 1. One of the many avocado accessions being maintained in The Huntington Botanical Gardens [in San Marino, California USA] living germplasm collection.

\subsubsection{Cryopreservation of avocado somatic embryos}

Somatic embryogenetic cultures are generally highly heterogeneous since they consist of embryos at different developmental stages [145]. Recovery of plantlets from somatic embryos and clonal multiplication in vitro is an essential step for commercial application of this technology to crop improvement [146]. Previous studies have shown that the percentage of high-quality bipolar embryos from avocado somatic embryos is extremely low at 2-3\% and is genotype dependent [147-149]. This low rate of somatic embryo conversion is 
currently the main bottleneck in avocado regeneration via somatic embryogenesis [146]. A recent study (has described an in vitro induction and multiplication system for somatic embryos of avocado, across four cultivars, which remained healthy and viable for 11 months, on a medium used for mango somatic embryogenesis [150]. Furthermore for one of the cultivars, cultivar 'Reed', a two-step regeneration system was developed that resulted in 43.3 $\%$ bipolar regeneration [150].

Information about cryopreservation of avocado somatic embryos is limited (Table 6). The effect of cryogenic storage on five avocado cultivars ('Booth 7', 'Hass', 'Suardia', 'Fuerte' and 'T362') using two cryopreservation protocols (controlled-rate freezing and classical-vitrification) has been reported [151]. In terms of controlled-rate freezing, three out of five embryogenic cultivars were successfully cryopreserved with a recovery of 53 to $80 \%$. Using classical-vitrification, cultivar 'Suardia' showed $62 \%$ recovery whereas 'Fuerte' had only a $5 \%$ recovery. Using droplet-vitrification on two 'Duke-7' embryogenic cell lines gave promising results, ranging from 78 to $100 \%$ recovery for both lines [88]. Protocols employed in both studies cannot be applied in general to multiple cultivars pointing to the need for more intensive research in this field.

Success with two cryopreservation protocols (cryovial and droplet-vitrification) for the conservation of avocado somatic embryos can be applied to multiple cultivars through the optimisation of loading sucrose concentrations and plant vitrification solution 2 (PVS2) temperature and times. Viability ranging from 59 to $100 \%$ with cryovial and dropletvitrification with somatic embryos of cultivars 'A10', 'Reed', 'Velvick' and 'Duke-7' after short and long-term LN exposure were achieved [146].

Table 6 Summary of successfully applied cryopreservation techniques to avocado somatic embryos. *Recovery is defined as any somatic embryo clump which was proliferating into new callus clumps.

\begin{tabular}{|l|l|l|}
\hline $\begin{array}{l}\text { Cryopreservation } \\
\text { Technique }\end{array}$ & Cultivar/s & $\begin{array}{l}\text { *Recovery } \\
\text { Percentages }\end{array}$ \\
\hline Classical vitrification & $\begin{array}{l}\text { 'Suardia' } \\
\text { 'Fuerte' }\end{array}$ & $\begin{array}{l}62 \% \\
5 \%[151]\end{array}$ \\
\hline Slow freezing & 'Suardia' & $60-80 \%$ \\
\hline
\end{tabular}




\begin{tabular}{|c|c|c|}
\hline & $\begin{array}{l}\text { 'T362' } \\
\text { 'Fuerte' }\end{array}$ & $\begin{array}{l}4-53 \% \\
73-75 \%[151]\end{array}$ \\
\hline Droplet vitrification & $\begin{array}{l}\text { Two lines of 'Duke 7' } \\
\text { 'A10' } \\
\text { 'Reed' } \\
\text { 'Velvick' }\end{array}$ & $\begin{array}{l}78-100 \%[88] \\
100 \%[146] \\
85 \%[146] \\
93 \%[146]\end{array}$ \\
\hline Cryovial vitrification & $\begin{array}{l}\text { 'A10' } \\
\text { 'Reed' } \\
\text { 'Velvick' } \\
\text { 'Duke 7' }\end{array}$ & $\begin{array}{l}91 \% \\
73 \% \\
86 \% \\
80 \%[146]\end{array}$ \\
\hline
\end{tabular}

\subsubsection{Shoot-tip cryopreservation of avocado}

Shoot-tip cryopreservation is a novel approach which can be used to conserve 'true-totype' avocado plant tissue. It is clonal and true to the accession being preserved without any heterogeneity. Shoot tips from various accessions can be collected from the field without waiting for avocado fruit development. The conserved shoot tips can be tagged with the exact phenotypic parameters in the field serving as an excellent back-up source that can be maintained in vitro.

However, to date, very few studies have focused on cryopreservation of avocado shoot tips. It was shown that axillary buds of Mexican and Guatemalan races were viable through fluorescein diacetate staining after dehydration with sterile air and being treated with cryopreservation solutions; however, shoot regeneration has not been achieved with the cryopreserved material [152]. Another study, showed that dehydration at 60 mins with sterile air and 30 mins in PVS4 at $0{ }^{\circ} \mathrm{C}$ produced normal plant development and $100 \%$ survival was obtained after 30, 45 and 60 days minus LN [153].

The development of a shoot-tip cryopreservation methodology is highly dependent on the availability of a reliable tissue culture multiplication and regeneration protocol for Persea spp. from physically mature plants. Although still cultivar-dependant, protocols have been established for multiple cultivars of avocado [110] advancing cryopreservation of avocado. 


\subsection{Critical factors identified for successful cryopreservation of shoot-tips}

\subsubsection{Advantages of vitrification-based procedures}

Vitrification-based procedures offer practical advantages in comparison to classical freezing techniques and are more appropriate for complex organs e.g., embryos and shoot tips, which contain a variety of cell types, each with unique requirements under conditions of freezeinduced dehydration [38]. The other advantage vitrification has over other cryopreservation techniques is that glass is viscous and stops all chemical reactions that require molecular diffusion, which leads to dormancy and stability over time [51]. Water is considered very difficult to vitrify as compared to glycerol, which is very viscous and can be supercooled to $70{ }^{\circ} \mathrm{C}$ without the formation of ice crystals [29]. Samples can be vitrified and rapidly supercooled at low temperatures and form in a solid metastable glass with crystallization [77]. For procedures that involve vitrification, cell dehydration occurs using a concentrated cryoprotective media and/or air desiccation and is performed first before rapid freezing in LN [38]. It is important that cells are not damaged or injured during the vitrification process and are vitrified enough to sustain immersion in LN [17]. As a result, all factors that affect intracellular ice formation are avoided [38].

\subsubsection{Oxidative stress associated with excision injury}

When cells are damaged during extraction, the cytoplasm and vacuoles are mixed and phenolic compounds can readily become oxidized by air, peroxidase or polyphenol oxidase. Oxidization of phenolic compounds may inhibit enzyme activity and result in darkening of the culture medium and subsequent lethal browning of explants [154].

Wounding can lead to an increase of reactive oxygen species (ROS) within the shoot therefore affecting the viability. ROS are highly reactive molecules and have been shown to cause damage in cells. Many molecules are considered as ROS, some of which include oxygenfree radical species and reactive oxygen non-radical derivatives [44]. The most common ROS species found in plants are superoxide (O2-), hydroperoxyl $(\mathrm{OOH})$, hydroxyl radical $(\mathrm{OH})$ and singlet oxygen (O2) [44]. Plants produce superoxide and singlet oxygen as by-products of photosynthesis and hydroxyl radicals and hydroperoxyl are commonly formed in a process called Fenton's reaction where hydrogen peroxide is converted into hydroxyl or hydroperoxyl radicals (1) [44]. ROS species are responsible for disrupting cellular activity through oxidative damage [155] through lipid peroxidation, which generate hydroxyl radicals that can damage vital cellular proteins and DNA [156]. This can be overcome by adding specific chelating agents which reduces the hydroxyl radical [49, 157-158]. 


\subsubsection{Role of antioxidants in reducing browning of cryopreserved shoot tips}

It has been reported by several authors that the addition of antioxidants can help increase the viability of plants by suppressing browning which leads to shoot tip death [70, 155, 159-162]. By maintaining a higher antioxidant level protection improved post cryopreservation [159]. It was suggested that a higher antioxidant level was present in a cold tolerant Ribes genotype, whereas the cold sensitive genotype which had poor post cryopreservation tolerance had low antioxidant levels [70, 155, 159-162].

The antioxidant ASA or vitamin C (ASA) occurs naturally in plants, in plant tissue and meristems. ASA has many roles in a plant's physiological processes but mainly in its defence against oxidative damage resulting from aerobic metabolism, photosynthesis, pollutants and other stresses caused by the environment [163]. Thus, ASA has an important role in the detoxification of ROS species both enzymatically or non-enzymatically [164]. ASA can do this by scavenging a singlet oxygen, hydrogen peroxide, superoxide and hydroxyl radical [163]. It has been reported that in Hordeum vulgare (barley) and Triticum aestivum (wheat) the addition of ASA in regrowth media improved the survival after cryopreservation by reducing lipid peroxidation [165]. The addition of ASA to pre-culture media, loading solution, unloading solution and regrowth media significantly increased regrowth of shoot tips of Rubus spp. (blackberry) [161].

\subsubsection{The toxic effects of cryoprotective agents}

In order to improve on tolerance to cryoprotectants and increase permeation of the cryoprotectant through the cell membrane and induce tolerance to dehydration caused by vitrification solutions, a pre-step called 'loading' is used [56]. Loading is usually achieved by incubating tissues for 10-20 min in solutions composed of glycerol and sucrose [44]. This loading step is particularly useful for plant species that are sensitive to direct exposure to cryoprotectants due to dehydration intolerance and osmotic stresses [44].

However, in some cases, use of loading solution alone is not adequate to induce tolerance to cryoprotectants, and other pre-treatments/pre-culture such as osmotic conditioning with sugars and cold acclimatisation are necessary [166]. For success in cryopreservation of Carica papaya shoot tips, the critical parameters were duration of pre-culture, duration and temperature of cryoprotectant (PVS2) exposure and the type and concentrations of plant growth regulators in the regeneration media [167]; and optimizing the dehydration tolerance of samples in vitrifying solution $[56,168]$. This tolerance can be improved by optimizing the pre- 
conditioning and loading treatments along with the standardization of concentration, time of exposure and temperature of vitrification solution. Re-warming and recovery steps are also crucial for success of cryopreservation protocols [56, 168].

\subsubsection{The role of cold acclimitization}

Water availability and temperature are influenced by environmental variables and are the major determinants of plant growth and development [169]. Most tropical and sub-tropical species have little to no freezing tolerance, however, temperate plant species have evolved some form of cold tolerance [169-170]. It has been shown in temperate plants that they have the genetic ability to increase cold tolerance significantly when exposed to environmental cues that signal the arrival of winter [171]. Many plants can increase their tolerance to the cold by exposure to lower temperatures, generally with temperatures below $10{ }^{\circ} \mathrm{C}$ [171]. This process is referred to as cold hardening or cold acclimatization (CA) and requires days to weeks for full development [54, 171-172]. Several biochemical, physiological and metabolic functions are altered in plants by low temperature as well as gene expression [173]. Expression of cold induced genes include those that control the function of cell membranes to stabilize and protect themselves against freezing injury [71]. Freezing tolerance can be increased by $2-8{ }^{\circ} \mathrm{C}$ in spring annuals, $10-30{ }^{\circ} \mathrm{C}$ in winter annuals and $20-200{ }^{\circ} \mathrm{C}$ in tree species [171]. CA has been used as an in vitro pre-treatment for donor plants in developing cryopreservation protocols in plants such as Malus domestica Borkh, Malus sieversii (Ledeb.) and Phoenix dactylifera [69, 174].

For temperate species and naturally occurring cold hardy plants, CA is very effective in the survival of cells after LN treatment [12] and the genotypes that do not cold acclimate well are difficult to cryopreserve [175]. This is because of the lipid and protein compositions of plasma membrane that dynamically alter during CA enhancing the cryo stability of the plasma membrane during ultra-cooling [176]. The cold acclimatization enhances the uptake of sugar from the media in sugar beet shoot tips, which safeguards the liquid crystalline state of membrane bilayers [177]. The decrease in the temperature increases the unsaturation of membrane lipids [178], which have a direct correlation in maintaining the fluid state in hydrocarbon chains at low temperature [179] and is crucial for the proper functioning and survival of cells [180]. It has been suggested that abscisic acid (ABA) can be substituted for the low temperature stimulus, provided there is also an adequate supply of sugars [181-182]. It has also been suggested that there may be ABA-dependent and ABA-independent pathways involved in the acclimatization process [72]. 
There have been several proteins that have been found to accumulate in plants when exposed to cold conditions and thus associated with developing cold tolerance [183]. Cold tolerant proteins include dehydrins, which are glycine-rich, hydrophilic, D-II LEA (late embryogenesis abundant) and thermostable. These proteins are known to associate with the nucleus, in the cytosol, and with the plasma membrane [183]. Dehydrins are thought to be highly-conserved polar regions and bond to hydrogen regions of macromolecules, acting essentially as a surfactant and preventing coagulation when cells are exposed to dehydration or low temperatures conditions [183]. It has been shown that an acidic dehydrin localises in close proximity to the plasma membrane when plants are cold acclimatized, thus supporting the role of cryoprotection of the plasma membrane during dehydration and freezing stress [184].

Cold acclimatization can help improve the regrowth rates of in vitro plants, improve regeneration rates and is usually used on donor plants before shoot tip extraction [185]. Cold acclimatization with or without ABA significantly improved the survival of Rubus [175]. ABA pre-treatment alone could not increase the survival of plants grown under warm conditions after cryopreservation, but the survival tripled when cold acclimatization was combined with ABA pre-treatment [175].

\subsubsection{The role of pre-culture with sucrose}

Pre-culturing shoot tips with a high sugar enriched media has been reported previously by several authors $[66-67,186]$ to increase the viability post-cryopreservation by better preconditioning the shoot. It has also been shown that pre-culturing in high sucrose media enhances the acclimatization process to low temperature and stimulates osmotic dehydration [15]. In other studies, time of incubation in pre-culture solutions was critical to ensuring survival and high regrowth rates [61, 187]. However, periods of exposure to high sucrose concentrations can be detrimental to the recovery of shoot tips post-liquid nitrogen [61].

There have been attempts to use alternative sources of sugar in pre-culture media, such as, sorbitol or mannitol [188-191], glucose and fructose; all have shown no negative effects on post-cryopreservation survival [192]. However, most researchers prefer to use sucrose as the sugar source when adding to pre-culture media [192]. Sucrose has been found to be more beneficial in pre-culture as compared to sorbitol and mannitol as these two sugars were unable to support regrowth of olive somatic embryos [193]. Sorbitol was also shown not to have a positive effect on the regrowth of Digitalis lanata cell cultures [194]. However, when $0.2 \mathrm{M}$ 
sorbitol was combined with $5 \%$ DMSO it was an effective cryoprotectant for embryogenic tissue of Pinus roxburghii Sarg. [195].

Sucrose is an excellent glass former and is able to stabilise membranes and proteins [196]. Sucrose stimulates the production of other elements such as proline, glycine betaine, glycerol and polyamines, which have colligative as well as non-colligative effects [197-198]. Of the above-mentioned sugars [199], glycerol [200], proline [201] and glycine betaine [202] have proved their cryoprotectant ability, whereas polyamines are known for their antioxidant properties. Therefore, these compounds play a vital role in protecting the cells during cryopreservation.

In Solanum spp., genotype plays a critical role into which pre-treatment is best for regrowth of shoot tips after cryopreservation, i.e., sucrose or cold treatment [203]. An accumulation of sugar especially sucrose and the raffinose family oligosaccharides (RFOs) in potato shoot tips can be linked to increased tolerance towards cryopreservation [203]. A reduction in and a reduced water content was able to help prepare Solanum spp. for cryopreservation treatments [203]. Many other authors, [172, 204-206] have shown that sucrose pre-treatment and cold treatment prior to exposure to cryopreservation improves recovery results.

\section{Avocado shoot tip conservation}

There have been significant improvements within the cryopreservation platform to preserve Persea spp. germplasm [207-209]. Cryopreservation protocols can cause several stresses both osmotic and temperature related, i.e., exposure to low temperature, exposure to highly concentrated cryoprotectants and freezing injury [160]. This can lead to an increase of ROS production affecting viability [210]. The role of antioxidants such as ASA (100 $\left.\mathrm{mg} \mathrm{L}^{-1}\right)$ [208] in reducing browning of avocado shoot tips, the use of pre-treatments such as sucrose and cold treatment to improve regrowth of shoot tips exposed to cryoprotectants are key players for developing a shoot-tip cryopreservation protocol for avocado [207].

Results obtained for two avocado cultivars clearly showed that while pre-treatments are effective for avocado, the type of pre-treatment needed and the degree of effectiveness was cultivar-specific [207]. This can be directly linked to the genetics of the two cultivars which display varying tolerance to cold and salinity in their natural growing environments. Correctly treating avocado shoot tips with the ideal pre-treatment before LN is vital for a successful outcome during the development of cryopreservation protocols [207]. 
The type of cryoprotectant and exposure time to the cryoprotectant was also vital in obtaining morphologically normal and vigorous plants [209]. Using the droplet vitrification technique combined with VSL produced positive results with two avocado cultivars belonging to different ecological races; cv 'Velvick' from West Indian race (no cold tolerance) and cv 'Reed' from Guatemalan race (moderate cold tolerance) [209]. Avocado shoots that survived LN grew into full plants ready for rooting after 24 weeks [209]. Cultivar 'Reed' shoots were successfully rooted [127] and after 8 weeks, plantlets were ready to be acclimatized in a glasshouse (Fig. 2). These plants will be screened for growth parameters and yield in a field trial at Duranbah, Queensland. Shoot tips from cv 'Velvick' are currently in the rooting stage.

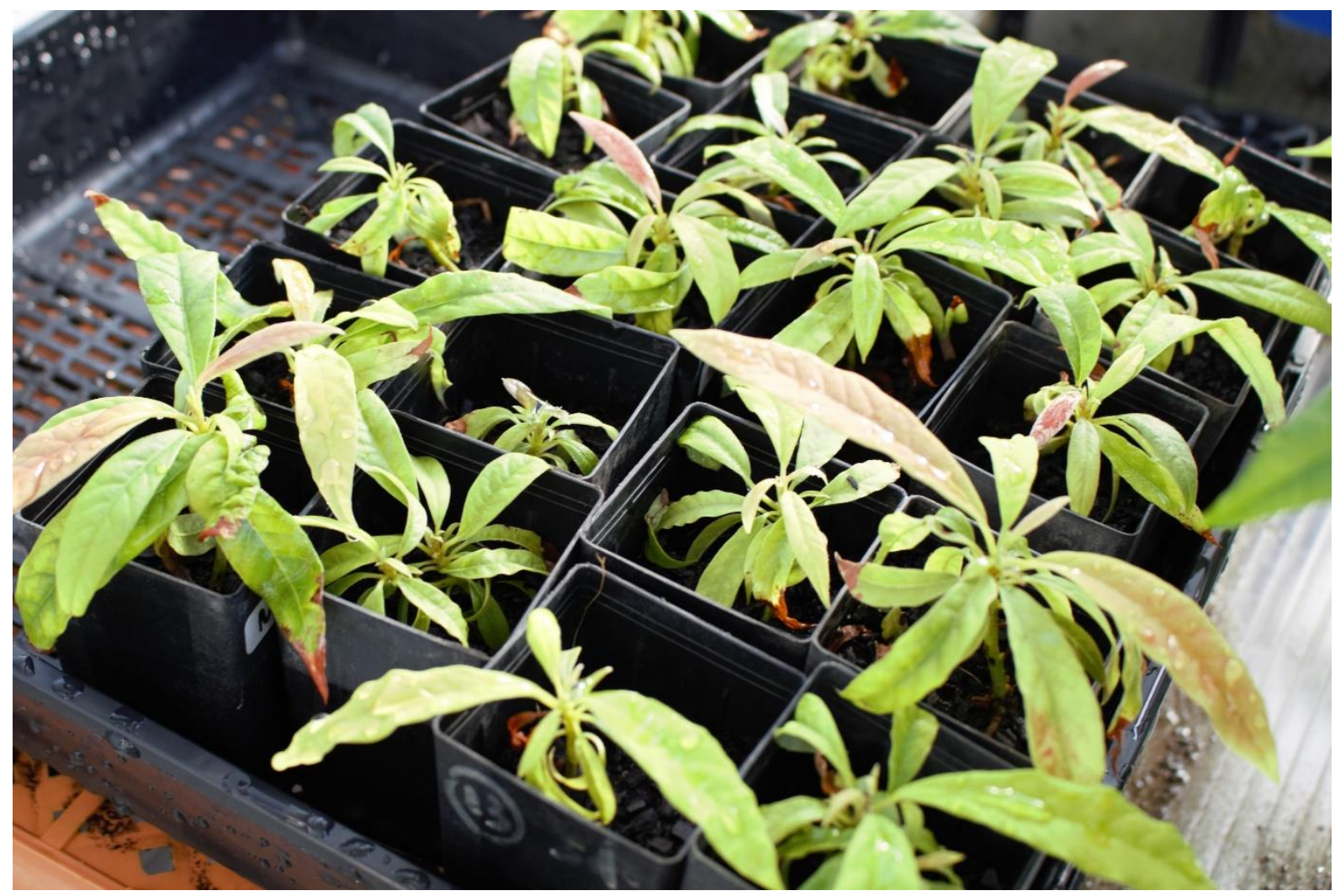

Fig. 2. Shoot tips of cv 'Reed' treated with VSL and revived from LN growing in a glasshouse.

\section{Conclusion}

Natural disasters, such as fires, drought, the recent COVID-19 pandemic, are a real threat to conservation of biodiversity. The number of genotypes held in a field bank is restricted by human, financial and land resources, thereby limiting genetic diversity. Cryopreserving a core collection rather than duplicating germplasm at various sites requires less space; the higher the number of accessions, the lower the unit cost. Vitrification-based cryopreservation 
techniques for both temperate and tropical plants species show potential for long-term conservation of plant diversity. Cryopreservation is an invaluable tool for securely preserving plant species with recalcitrant seeds that cannot tolerate desiccation to low moisture contents and only remain viable for a short time, e.g., avocado.

New advances in the tissue culture platform for avocado have enabled development of cryopreservation protocols. Based on the positive results, globally, this new cryopreservation platform provides the capacity to clonally cryopreserve this important crop. This is an immeasurably valuable tool to the avocado industry securely preserving valuable clonal rootstock with their specific genetic traits in a naturally outcrossing species for future breeding programmes. It is an important outcome particularly for elite novel varieties protected by Plant Breeders Rights when complete genetic conservation of characteristics is essential. The world's first germplasm repository to store a core collection of Persea spp. for true-to-type avocado shoot tip preservation is now an achievable goal.

\section{Acknowledgements}

The Queensland Alliance for Agriculture and Food Innovation (QAAFI) is a research institute of The University of Queensland (UQ), supported by the Queensland Government Department of Agriculture and Fisheries. Chris O'Brien is supported by an Australian Commonwealth Government Research Training Program (RTP) Scholarship and funding from The Huntington Library, Art Museum, and Botanical Gardens as well as funding from Advance Queensland Innovation Partnerships Project Avocado Tissue-Culture: From Lab-to-Orchard (AQIP06316-17RD2).

The authors would also like to acknowledge the following people for providing information on avocado germplasm collections Professor Mary Lu Arpaia, Mr Eric Focht, Dr Patricia Manosalva, Professor Alejandro Barrientos-Priego, Dr Tatiana Cantuarias, Dr Elizabeth Dann, Dr Ricardo Goenaga. We also acknowledge Dr Christina Walters, Dr Kim E. Hummer and Dr Gan-Yuan Zhong for information on clonal germplasm repositories.

\section{References}

1. Wilson, E., The Diversity of Life; Penguin:London, 1992.

2. Jalli, R.; Aravind, J.; Pandey, A., Conservation and management of endemic and threatened plant species in India: An overview. In Plant Biology and Biotechnology, Bahadur, B., Venkat, R. M., Sahijram, L., Krishnamurthy, K., Eds. Springer: New Delhi, 2015; pp 461-486, doi:10.1007/978-81-322-2283-5_24.

3. Maxted, N.; Guarino, L.; Myer, L.; Chiwona, E., Towards a methodology for on-farm conservation of plant genetic resources. Genetic Resources and Crop Evolution 2002, 49 (1), 31-46. 
4. $\quad$ Engelmann, F.; Engels, J., Technologies and strategies for ex situ conservation. In Managing Plant Genetic Diversity, Engels, J. M., Ramanatha, R. U., Brown, A. H. D., Jackson, M. T. Eds., CAB International: Wallingford, 2002; pp 89-103, ISBN: 9780851995229 , doi:10.1079/9780851995229.0089.

5. Engelmann, F., Use of biotechnologies for the conservation of plant biodiversity. In Vitro Cellular \& Developmental Biology - Plant 2011, 47 (1), 5-16, 10.1007/s11627-010-9327-2.

6. Acedo, V.; Arradoza, C., In vitro conservation of yam germplasm. Philippine Journal of Crop Science (Philippines) 2005.

7. $\quad$ Reed, B.; Bell, R., In vitro tissue culture of pear: advances in techniques for micropropagation and germplasm preservation. In Proceedings of VIII International Symposium on Pear 596, 2000; pp 412-418, ISBN: 9066058668 , doi:10.17660/ActaHortic.2002.59666.

8. $\quad$ Bertrand-Desbrunais, A.; Noirot, M.; Charrier, A., Slow growth in vitro conservation of coffee (Coffea spp.). Plant Cell, Tissue and Organ Culture 1992, 31 (2), 105-110, doi:10.1007/BF00037693.

9. $\quad$ Engelmann, F., In vitro conservation methods. In Biotechnology and Plant Genetic Resources: Conservation and Use, Callow, J. A., Ford-Lloyd, B. V., Newburry, J. H., Eds. CABI: Wallingford, 1997; pp 119-162, ISBN: 0851991424.

10. George, E. F.; Sherrington, P. D., Plant propagation by tissue culture: handbook and directory of commercial laboratories. In Journal of Basic Microbiology, Schmauder, H. P., Ed. Exegetics Ltd.: Eversley, UK, 1984; ISBN: 0950932507, doi:10.1002/jobm.3620250714.

11. Reed, B. M.; Gupta, S.; Uchendu, E. E., In vitro genebanks for preserving tropical biodiversity. In Conservation of Tropical Plant Species, $1^{\text {st }}$ ed.; Normah, M. N., Chin, H. F., Reed, B. M., Eds. Springer New York: New York, NY, 2013; pp 77-106, ISBN: 978-1-4614-3776-5., doi:10.1007/978-1-4614-3776-5_5.

12. Benson, E. E., Cryopreservation theory. In Plant Cryopreservation: A Practical Guide, Reed, B. M. Eds., Springer: New York, NY, 2008; pp 15-32, ISBN: 978-0-387-72275-7, doi:10.1007/978-0-387-72276-4_2.

13. Benelli, C.; de Carlo, A.; Engelmann, F., Recent Advances in the cryopreservation of shoot-derived germplasm of economically important fruit trees of Actinidia, Diospyros, Malus, Olea, Prunus, Pyrus and Vitis. Biotechnology Advances 2013, 31 (2), 175-185, doi:10.1016/j.biotechadv.2012.09.004.

14. Engelmann, F., Germplasm collection, storage, and conservation. In Plant Biotechnology and Agriculture. Prospects for $21^{\text {st }}$ Century, Altman, A., Hagegawa, A. Eds., Academic Press: San Diego CA USA, 2012; pp 255-267, doi:10.1016/B9780-12-381466-1.00017-1.

15. Reed, B. M., Plant Cryopreservation: A Practical Guide. Reed, B. M., Ed. Springer New York:, 2008; ISBN: 978$0-387-72275-7$

16. Engelmann, F., Cryopreservation of embryos: an overview. In Plant Embryo Culture, Methods in Molecular Biology (Methods and Protocols.), Thorpe, T. A., Yeung, E. C., Eds. Humana Press: 2011; Vol. 710, pp 155-84, ISBN: 978-1-61737987-1, doi: 10.1007/978-1-61737-988-8_13.

17. $\quad$ Bi, W. L.; Pan, C.; Hao, X. Y.; Cui, Z. H.; Kher, M.; Marković, Z.; Wang, Q. C.; Teixeira da Silva, J., Cryopreservation of grapevine (Vitis spp.) - a review. In Vitro Cellular \& Developmental Biology - Plant 2017, 53 (5), 449 460, doi:10.1007/s11627-017-9822-9.

18. Bettoni, J. C.; Costa, M. D.; Gardin, J. P. P.; Kretzschmar, A. A.; Pathirana, R., Cryotherapy: a new technique to obtain grapevine plants free of viruses. Revista Brasileira de Fruticultura 2016, 38 (2), doi:10.1590/0100-29452016833.

19. Wang, Q.; Valkonen, J. P., Cryotherapy of shoot tips: novel pathogen eradication method. Trends Plant Sci 2009, 14 (3), 119-22, doi:10.1016/j.tplants.2008.11.010.

20. $\quad$ Streczynski, R.; Clark, H.; Whelehan, L. M.; Ang, S.-T.; Hardstaff, L. K.; Funnekotter, B.; Bunn, E.; Offord, C. A.; Sommerville, K. D.; Mancera, R. L., Current issues in plant cryopreservation and importance for ex situ conservation of threatened Australian native species. Australian Journal of Botany 2019, 67 (1), 1-15, doi.org/10.1071/BT18147.

21. Ashmore, S. E., Status Report on the Development and Application of in vitro Techniques for the Conservation and Use of Plant Genetic Resources. International Plant Genetic Resources Institute: Rome, Italy, 1997; ISBN: 9290433396.

22. $\quad$ Mandal, B.; Tyagi, R.; Pandey, R.; Sharma, N.; Agrawal, A., In vitro conservation of germplasm of agri-horticultural crops at NBPGR: an overview. In Conservation of Plant Genetic Resources in vitro, Razdan, M. K., Cocking, E. C. Eds., Science Publishers Inc: USA, 2000; Vol. 2, pp 297-307.

23. Reed, B. M.; Denoma, J.; Wada, S.; Postman, J., Micropropagation of pear (Pyrus spp.). Methods Mol Biol 2013, $11013,3-18$

24. Withers, L. A.; Engelmann, F., In vitro conservation of plant genetic resources. In Agricultural Biotechnology, Altman, A., Ed. Marcel Dekker: New York, 1998; pp 57-88, ISBN: 0-8247-9439-7.

25. F.A.O., Genebank standards: For Plant Genetic Resources for Food and Agriculture. Food and Agriculture Organization of the United Nations: Rome, 2014; ISBN: 978-92-5-108262-1.

26. Reed, B. M.; Engelmann, F.; Dulloo, M. E.; Engels, J. M. M., Technical Guidelines for the Management of Field and in vitro Germplasm Collections. IPGRI Handbooks for Genebanks No. 7. International Plant Genetic Resources Institute. Rome, Italy, 2004; Vol. 472, ISBN: 9290436409.

27. Benson, E.; Harding, K.; Debouck, D. G.; Dumet, D.; Escobar, R.; Mafla, G.; Panis, B.; Panta, A.; Tay, D.; Houwe, I., Refinement and standardization of storage procedures for clonal crops. Global Public Goods Phase 2: Part 1. Project landscape and general status of clonal crop in vitro conservation technologies. System-Wide Genetic Resources Programme (SGRP): Rome, Italy, 2011; ISBN: 929043905X

28. Benson, E.; Harding, K.; Debouck, D. G.; Dumet, D.; Escobar, R.; Mafla, G.; Panis, B.; Panta, A.; Tay, D.; Houwe, I., Refinement and standardization of storage procedures for clonal crops. Global Public Goods Phase 2. Part 2: Status of in vitro conservation technologies for: Andean root and tuber crops, cassava, Musa, potato, sweetpotato and yam. System-Wide Genetic Resources Programme (SGRP): Rome, Italy, 2011; ISBN: 9290439068.

29. Panis, B.; Thinh, N. T., Cryopreservation of Musa germplasm, INIBAP Technical Guideline 5; Escalant, J. V., Sharrock, S., Eds. International Network for the Improvement of Banana and Plantain: Montpellier, France, 2001. 
30. Niino, T.; Arizaga, M. V., Cryopreservation for preservation of potato genetic resources. Breeding Science 2015, 65 (1), 41-52, doi:10.1270/jsbbs.65.41.

31. Panta, A.; Panis, B.; Ynouye, C.; Swennen, R.; Roca, W.; Tay, D.; Ellis, D., Improved cryopreservation method for the long-term conservation of the world potato germplasm collection. Journal of Plant Biotechnology 2015, 120 (1), 117-125, doi:10.1007/s11240-014-0585-2.

32. Dulloo, M.; Ebert, A. W.; Dussert, S.; Gotor, E.; Astorga, C.; Vasquez, N.; Rakotomalala, J.; Rabemiafara, A.; Eira, M.; Bellachew, B., Cost efficiency of cryopreservation as a long-term conservation method for coffee genetic resources. Crop Science 2009, 49 (6), 2123-2138, doi:10.2135/cropsci2008.12.0736.

33. Keller, E. R. J.; Senula, A.; Leunufna, S.; Grübe, M., Slow growth storage and cryopreservation - tools to facilitate germplasm maintenance of vegetatively propagated crops in living plant collections. International Journal of Refrigeration 2006, 29 (3), 411-417, doi:10.1016/j.ijrefrig.2005.07.012.

34. Gopal, J.; Sukh Chauhan, N., Slow Growth in vitro conservation of potato germplasm at low temperature. Journal of the European Association for Potato Research 2010, 53 (3), 141-149, doi:10.1007/s11540-010-9158-x.

35. Status of Collections at National Genebank (NGB), ICAR-NBPGR, New Delhi http://www.nbpgr.ernet.in/Research_Projects/Base_Collection_in_NGB.aspx (accessed 3.11.2020).

36. Gutierrez, B., Personal communication, USDA-ARS Plant Genetic Resources Unit, Geneva, New York, USA, 2020. 37. Walters, C., Personal communication, USDA Agricultural Genetic Resources Preservation Research, Fort Collins, $\mathrm{CO}, 2020$.

38. Engelmann, F., Plant cryopreservation: Progress and prospects. In Vitro Cellular \& Developmental Biology - Plant 2004, 40 (5), 427-433, doi:10.1079/IVP2004541.

39. Berjak, P.; Pammenter, N. W., Implications of the lack of desiccation tolerance in recalcitrant seeds. Front Plant Sci 2013, 4, 478, doi:10.3389/fpls.2013.00478.

40. $\quad$ Neya, O., Conservation of tree seeds from tropical dry-lands 2006.

41. Berjak, P.; Pammenter, N., Seed recalcitrance-current perspectives. South African Journal of Botany 2001, 67 (2), 79-89, doi:10.1016/s0254-6299(15)31111-x.

42. Engelmann, F., Germplasm collection, storage, and conservation. In Plant Biotechnology and Agriculture, Altman A, Hagegawa A ed.; Academic Press: San Diego CA USA, 2012; pp 255-267, ISBN:9780123814661, doi:10.1016/b978-012-381466-1.00017-1.

43. Cruz-Cruz, C. A.; González-Arnao, M. T.; Engelmann, F., Biotechnology and conservation of plant biodiversity. Resources 2013, 2 (2), 73-95, doi:10.3390/resources2020073.

44. Kaczmarczyk, A.; Funnekotter, B.; Menon, A.; Phang, P. Y.; Al - Hanbali, A.; Bunn, E.; Mancera, R., Current issues in plant cryopreservation. In Current Frontiers in Cryobiology, Katkov, I. I., Ed. In Tech: Crotia, 2012; pp 417-438, ISBN: 978-9535101918.

45. Kaczmarczyk, A.; Rokka, V.-M.; Keller, E. R. J., Potato shoot tip cryopreservation. A review. Potato Research 2011, 54 (1), 45-79, doi:10.1007/s11540-010-9169-7.

46. Benson, E., An introduction to plant conservation biotechnology. In Plant Conservation Biotechnology, Benson, E., Ed. Taylor \& Francis Inc: USA, 1999; ISBN: 0-203-48419-3.

47. Uchendu, E. E.; Reed, B. M., A comparative study of three cryopreservation protocols for effective storage of in vitro-grown mint (Mentha spp.). CryoLetters 2008, 29 (3), 181-188.

48. Bajaj, Y., Freeze preservation of meristems of Arachis hypogaea and Cicer arietinum [Groundnut, chickpea, India]. Indian Journal of Experimental Biology (India) 1979.

49. Benson, E. E., Cryopreservation of shoot-tips and meristems. In Cryopreservation and Freeze-Drying Protocols, Methods in Molecular Biology, Day, J. G., Pennington, M. W., Eds. Humana Press: Totowa, 1995; pp 121-132, ISBN: 978-089603-296-5, doi:10.1385/0-89603-296-5:121.

50. Gonzalez-Arnao, M. T.; Panta, A.; Roca, W. M.; Escobar, R. H.; Engelmann, F., Development and large scale application of cryopreservation techniques for shoot and somatic embryo cultures of tropical crops. Plant Cell, Tissue and Organ Culture 2008, 92 (1), 1-13, doi:10.1007/s11240-007-9303-7.

51. Burke, M. J., The glass state and survival of anhydrous biological systems. Membranes, Metabolism, and Dry Organisms 1986, 358-363.

52. Mišianiková, A.; Zubrická, D.; Petijová, L.; Bruňáková, K.; Čellárová, E., Effect of cryoprotectant solution and of cooling rate on crystallization temperature in cryopreserved Hypericum perforatum cell suspension cultures. CryoLetters 2016, 37 (3), 173-187.

53. Sakai, A.; Hirai, D.; Niino, T., Development of PVS-based vitrification and encapsulation-vitrification protocols. In Plant Cryopreservation: A Practical Guide, Reed, B. M., Ed. Springer: New York, NY, 2008; pp 33-57, ISBN: 978-0-38772275-7, doi:10.1007/978-0-387-72276-4_3.

54. Panis, B.; Lambardi, M., Status of cryopreservation technologies in plants (crops and forest trees). In The Role of Biotechnology in Exploring and Protecting Agricultural Genetic Resources, Ruane, J., Sonnino, A., Eds. Food \& Agriculture Org: Rome, 2006; pp 61-78, ISBN: 92-5-105480-0.

55. Pérez, R. M., Cryostorage of Citrus embryogenic cultures In Somatic Embryogenesis in Woody Plants, Jain, S. M., Gupta, P. K., Newton, R. J., Eds. Springer: Dordrecht, 2000; Vol. 67, pp 687-705, ISBN: 978-90-481-5508-8, doi:10.1007/97894-017-3030-3_25.

56. Sakai, A.; Engelmann, F., Vitrification, encapsulation-vitrification and droplet-vitrification: a review. CryoLetters 2007, 28 (3), 151-172.

57. Tanino, K. K.; Chen, T. H. H.; Fughigami, L. H.; Weiser, C. J., Metabolic alterations associated with abscisic acidinduced frost hardiness in bromegrass suspension culture cells. Plant Cell Physiol 1990, 31, 505-511, doi:10.1093/oxfordjournals.pcp.a077938. 
58. Sakai, A.; Kobayashi, S.; Oiyama, I., Cryopreservation of nucellar cells of navel orange (Citrus sinensis Osb. var. brasiliensis Tanaka) by vitrification. Plant Cell Reports 1990, 9 (1), 30-33, doi:10.1007/BF00232130.

59. Nishizawa, S.; Sakai, A.; Amano, Y.; Matsuzawa, T., Cryopreservation of asparagus (Asparagus officinalis L.) embryogenic suspension cells and subsequent plant regeneration by vitrification. Plant Science 1993, 91 (1), 67-73, doi:10.1016/0168-9452(93)90189-7.

60. Kim, H.-H.; No, N.-Y.; Shin, D.-J.; Ko, H.-C.; Kang, J.-H.; Cho, E.-G.; Engelmann, F., Development of alternative plant vitrification solutions to be used in droplet-vitrification procedures. Acta Hortic: 2011; Vol. 908, pp 181-186, doi:10.17660/ActaHortic.2011.908.20.

61. Azimi, M.; O'Brien, C.; Ashmore, S.; Drew, R., Cryopreservation of papaya germplasm. Acta Horticulturae 2005, 692 (692), 43-50, doi:10.17660/ActaHortic.2005.692.4.

62. Yamada, T.; Sakai, A.; Matsumura, T.; Higuchi, S., Cryopreservation of apical meristems of white clover (Trifolium repens L.) by vitrification. Plant Science 1991, 78 (1), 81-87, doi:10.1016/0168-9452(91)90164-4.

63. McGann, L. E., Differing actions of penetrating and nonpenetrating cryoprotective agents. Cryobiology 1978, 15 (4), 382-390, doi:10.1016/0011-2240(78)90056-1.

64. Uragami, A.; Sakai, A.; Nagai, M., Cryopreservation of asparagus (Asparagus-officinalis L.) cultured in vitro. Jarq - Jpn. Agric. Res. Q. 1993, 27 (2), 112-115.

65. Uragami, A.; Sakai, A.; Nagai, M.; Takahashi, T., Survival of cultured cells and somatic embryos of Asparagus officinalis cryopreserved by vitrification. Plant Cell Reports 1989, 8 (7), 418-421, doi:10.1007/BF00270083.

66. $\quad$ Feng, C.-H.; Cui, Z.-H.; Li, B.-Q.; Chen, L.; Ma, Y.-L.; Zhao, Y.-H.; Wang, Q.-C., Duration of sucrose pre-culture is critical for shoot regrowth of in vitro-grown apple shoot-tips cryopreserved by encapsulation-dehydration. Plant Cell, Tissue and Organ Culture (PCTOC) 2013, 112 (3), 369-378, doi:10.1007/s11240-012-0245-3.

67. Kaczmarczyk, A.; Shvachko, N.; Lupysheva, Y.; Hajirezaei, M.-R.; Keller, E. R. J., Influence of alternating temperature pre-culture on cryopreservation results for potato shoot tips. Plant Cell Reports 2008, 27 (9), 1551-1558, doi:10.1007/s00299-008-0574-1.

68. Ozudogru, E. A.; Kaya, E., Cryopreservation of Thymus cariensis and T. vulgaris shoot tips: comparison of three vitrification-based methods. CryoLetters 2012, 33 (5), 363-375.

69. Kushnarenko, S. V.; Romadanova, N. V.; Reed, B. M., Cold acclimation improves regrowth of cryopreserved apple shoot tips. CryoLetters 2009, 30 (1), 47-54.

70. Mathew, L.; McLachlan, A.; Jibran, R.; Burritt, D. J.; Pathirana, R., Cold, antioxidant and osmotic pre-treatments maintain the structural integrity of meristematic cells and improve plant regeneration in cryopreserved kiwifruit shoot tips. Protoplasma 2018, 255 (4), 1065-1077, doi:10.1007/s00709-018-1215-3.

71. Thomashow, M. F., Plant cold acclimation: freezing tolerance genes and regulatory mechanisms. Annual Review of Plant Biology 1999, 50 (1), 571-599, doi:10.10046/annurev.arplant.50.1.571.

72. Xin, Z.; Browse, J., Cold comfort farm: the acclimation of plants to freezing temperatures. Plant, Cell \& Environment 2000, 23 (9), 893-902, doi:10.1046/j.1365-3040.2000.00611.

73. Matsumoto, T. Doctorial Thesis. 1999.

74. Suzuki, M.; Tandon, P.; Ishikawa, M.; Toyomasu, T., Development of a new vitrification solution, VSL, and its application to the cryopreservation of gentian axillary buds. Plant Biotechnology Reports 2008, 2 (2), 123, doi:10.1007/s11816-008-0056-5.

75. Langis, R.; Schnabel, B.; Earle, E.; Steponkus, P., Cryopreservation of Brassica campestris L. cell suspensions by vitrification. Cryo-Letters (United Kingdom) 1989.

76. Towill, L. E., Cryopreservation of isolated mint shoot tips by vitrification. Plant Cell Rep 1990, 9 (4), 178-80, doi:10.1007/bf00232174.

77. Fahy, G. M.; MacFarlane, D.; Angell, C.; Meryman, H., Vitrification as an approach to cryopreservation. Cryobiology 1984, 21 (4), 407-426, doi:10.10.16/0011-2240(84)90079-8.

78. Engelmann, F., Importance of cryopreservation for the conservation of plant genetic resources. Cryopreservation of tropical plant germplasm: current research progress and application. In Proceedings of an International Workshop, Tsukuba, Japan, October, 1998, International Plant Genetic Resources Institute (IPGRI): 2000; pp 8-20, ISBN: 9290434-287.

79. Yamamoto, S.-i.; Rafique, T.; Priyantha, W. S.; Fukui, K.; Matsumoto, T.; Niino, T., Development of a Cryopreservation Procedure Using Aluminium Cryo-plates. Cryoletters 2011, 32 (3), 256-265.

80. Adu-Gyamfi, R.; Wetten, A., Cryopreservation of cocoa (Theobroma cacao L.) somatic embryos by vitrification. CryoLetters 2012, 33 (6), 494-505.

81. $\quad$ Markovic, Z.; Chatelet, P.; Peyrière, A.; Preiner, D.; Engelmann-Sylvestre, I.; Karoglan-Kontić, J.; Engelmann, F., Effect of proline pre-treatment on grapevine shoot-tip response to a droplet-vitrification protocol. American Journal of Plant Sciences 2013, 4, 2414-2417, doi:104236ajps.2013.412299.

82. $\quad$ Marković, Z.; Chatelet, P.; Preiner, D.; Sylvestre, I.; Kontić, J. K.; Engelmann, F., Effect of shooting medium and source of material on grapevine (Vitis vinifera L.) shoot tip recovery after cryopreservation. CryoLetters 2014, 35 (1), 40-47. 83. Marković, Z.; Chatelet, P.; Sylvestre, I.; Kontić, J.; Engelmann, F., Cryopreservation of grapevine (Vitis vinifera L.) in vitro shoot tips. Central European Journal of Biology 2013, 8 (10), 993-1000, doi:10.2478/s11535-013-0223-8.

84. $\quad$ Marković, Z.; Preiner, D.; Stupić, D.; Andabaka, Ž.; Šimon, S.; Vončina, D.; Maletić, E.; Kontić, J. K.; Chatelet, P.; Engelmann, F., Cryopreservation and cryotherapy of grapevine (Vitis vinifera L.). Vitis 2015, 54 (SI), 247.

85. Pathirana, R.; McLachlan, A.; Hedderley, D.; Panis, B.; Carimi, F., Pre-treatment with salicylic acid improves plant regeneration after cryopreservation of grapevine (Vitis spp.) by droplet vitrification. Acta Physiologiae Plantarum 2016, 38 (1), 12, doi:10.1007s11738-015-2026-1.

86. Carimi, F.; Carra, A.; Panis, B.; Pathirana, R., Strategies for conservation of endangered wild grapevine (Vitis vinifera L. subsp. sylvestris (CC Gmel.) Hegi). Acta Hortic: 2016; Vol. 1115, pp 81-86, doi:10.17660/ActaHortic.2016.1115.13. 
87. Martinez-Montero, M. E.; Martinez, J.; Engelmann, F., Cryopreservation of sugarcane somatic embryos. CryoLetters 2008, 29, 229-242.

88. Guzmán-García, E.; Bradaï, F.; Sánchez-Romero, C., Cryopreservation of avocado embryogenic cultures using the droplet-vitrification method. Acta Physiologiae Plantarum 2013, 1-11, doi:10.1007/s11738-012-1062-3.

89. Shibli, R.; Al-Juboory, K., Cryopreservation of 'Nabali' olive (Olea europea 1.) somatic embryos by encapsulationdehydration and encapsulation-vitrification. CryoLetters 2000, 21 (6), 357-366.

90. Soliman, H. I., Cryopreservation of in vitro-grown shoot tips of apricot (Prunus armeniaca L.) using encapsulationdehydration. African Journal of Biotechnology 2013, 12 (12), doi:10.5897AJB12.2857.

91. Wang, Q.; Tanne, E.; Arav, A.; Gafny, R., Cryopreservation of in vitro-grown shoot tips of grapevine by encapsulation-dehydration. Plant Cell, Tissue and Organ Culture 2000, 63 (1), 41-46, doi:10.1023/a:1006411829738.

92. Dumet, D.; Engelmann, F.; Chabrillange, N.; Duval, Y., Cryopreservation of oil palm (Elaeis guineensis Jacq.) somatic embryos involving a dessication step. Plant Cell, Tissue and Organ Culture 1993, 12, 352-355, doi:10.1007/BF00237434.

93. Tessereau, H.; Florin, B.; Meschine, M. C.; Thierry, C.; Petiard, V., Cryopreservation of somatic embryos: a tool for germplasm storage and commercial delivery of selected plants. Annals of Botany 1994, 74 (5), 547 - 555, doi:10.1006/anbo.1994.1153.

94. González-Arnao, M. T.; Juarez, J.; Ortega, C.; Navarro, L.; Duran-Villa, N., Cryopreservation of ovules and somatic embryos of citrus using the encapsulation-dehydration technique. CryoLetters 2003, 24 (85-94).

95. Niino, T.; Yamamoto, S.; Matsumoto, T.; Engelmann, F.; Valle Arizaga, M.; Tanaka, D., Development of V and D cryo-plate methods as effective protocols for cryobanking. International Society for Horticultural Science (ISHS), Leuven, Belgium: 2019; pp 249-262, 2406-6168, 10.17660/ActaHortic.2019.1234.33.

96. Kim, H. H.; Kim, J. B.; Baek, H. J.; Cho, E. G.; Chae, Y. A.; Engelmann, F., Evolution of DMSO concentration in garlic shoot tips during a vitrification procedure. CryoLetters 2004, 25 (2), 90-100.

97. Kartha, K.; Leung, N.; Mroginski, L., In vitro growth responses and plant regeneration from cryopreserved meristems of cassava (Manihot esculenta Crantz). Zeitschrift für Pflanzenphysiologie 1982, 107 (2), 133-140, doi:10.1016/s0044-328x(82)80099-8.

98. Panis, B.; Lambardi, M., Status of cryopreservation technologies in plants (crops and forest trees). In The Role of Biotechnology in Exploring and Protecting Agricultural Genetic Resources, Ruane, J., Sonnino, A., Eds. Food \& Agriculture Org.: 2005; ISBN: 92-5-105480-0.

99. Bettoni, J. C.; Bonnart, R.; Volk, G. M., Challenges in implementing plant shoot tip cryopreservation technologies. Plant Cell Tissue and Organ Culture 2020, doi:10.1007/s11240-020-01846-2.

100. Panis, B.; Piette, B.; Swennen, R., Droplet vitrification of apical meristems: a cryopreservation protocol applicable to all Musaceae. Plant Science 2005, 168 (1), 45-55, doi:10.1016/j.plantsci.204.07.022.

101. Benson, E.; Harding, K.; Debouck, D. G.; Dumet, D.; Escobar, R.; Mafla, G.; Panis, B.; Panta, A.; Tay, D.; Houwe, I., Refinement and standardization of storage procedures for clonal crops. Global Public Goods Phase 2. Part 3: Multi-crop guidelines for developing in vitro conservation best practices for clonal crops. System-Wide Genetic Resources Programme (SGRP): Rome, Italy, 2011; ISBN: 9290438339.

102. Niino, T.; Sakai, A., Cryopreservation of alginate-coated in vitro-grown shoot tips of apple, pear and mulberry. Plant Science 1992, 87 (2), 199-206.

103. Paul, H.; Daigny, G.; Sangwan-Norreel, B., Cryopreservation of apple (Malus $\times$ domestica Borkh.) shoot tips following encapsulation-dehydration or encapsulation-vitrification. Plant Cell Reports 2000, 19 (8), 768-774.

104. Wang, Q.; Batuman, Ö.; Li, P.; Bar-Joseph, M.; Gafny, R., Cryopreservation of in vitro-grown shoot tips of'Troyer'citrange [Poncirus trifoliata (L.) Raf. $\times$ Citrus sinensis (L.) Osbeck.] by encapsulation-dehydration. Plant cell reports 2002, 20 (10), 901-906.

105. Wang, Q.; Batuman, Ö.; Li, P.; Bar-Joseph, M.; Gafny, R., A simple and efficient cryopreservation of in vitro-grown shoot tips ofTroyer'citrange [Poncirus trifoliata (L.) Raf.x Citrus sinensis (L.) Osbeck.] by encapsulation-vitrification. Euphytica 2002, 128 (1), 135-142.

106. Rohwer, J. G.; Li, J.; Rudolph, B.; Schmidt, S. A.; van der Werff, H.; Li, H.-w., Is Persea (Lauraceae) monophyletic? Evidence from nuclear ribosomal ITS sequences. Taxon 2009, 58 (4), 1153-1167, doi:10.1002/tax.584009.

107. Warschefsky, E. J.; Klein, L. L.; Frank, M. H.; Chitwood, D. H.; Londo, J. P.; von Wettberg, E. J.; Miller, A. J., Rootstocks: diversity, domestication, and impacts on shoot phenotypes. Trends in Plant Science 2016, 21 (5), 418-437, doi:10.1016/j.tplants.2015.11.008.

108. Avocado production. Available online: $\mathrm{https} / /$ horticulture.com.au/grower-focus/avocado/ (accessed 6.10.2020).

109. Dreher, M. L.; Davenport, A. J., Hass avocado composition and potential health effects. Crit Rev Food Sci Nutr 2013, 53 (7), 738-50, doi:10.1080/10408398.2011.556759.

110. Hiti-Bandaralage, J. C.; Hayward, A.; Mitter, N., Micropropagation of avocado (Persea americana Mill.). American Journal of Plant Sciences 2017, 8 (11), 2898-2921, doi:10.4236ajps.2017.811197.

111. Rendón-Anaya, M.; Ibarra-Laclette, E.; Bravo, A. M.; Lan, T.; Zheng, C.; Carretero-Paulet, L.; Perez-Torres, C. A.; Chacón-López, A.; Hernandez-Guzmán, G.; Chang, T.-H., The avocado genome informs deep angiosperm phylogeny, highlights introgressive hybridization, and reveals pathogen influenced gene space adaptation. Proc Natl Acad Sci USA 2019, 116 (34), 17081-17089, doi:10.1073/pnas.1822129116.

112. Arpaia, M. L. Avocado Brainstorming 2018, Towards a Sustainable Future; Tzaneen, South Africa, 28 May - 1 June 2018, 2018.

113. Smith, L.; Dann, E.; Pegg, K.; Whiley, A.; Giblin, F.; Doogan, V.; Kopittke, R., Field assessment of avocado rootstock selections for resistance to Phytophthora root rot. Australasian Plant Pathology 2011, 40 (1), 39-47, doi:10.1007/s13313-010-0011-0. 
114. Ben-Ya'acov, A. A.; López López, L.; de la Cruz Torres, E.; Barrientos Priego, A. F., A study of avocado germplasm resources, 1988-1990. II.-Findings from the central part of México. In Proceedings of Second World Avocado Congress, 1992; pp 543-544.

115. Ge, Y.; Zhang, T.; Wu, B.; Tan, L.; Ma, F.; Zou, M.; Chen, H.; Pei, J.; Liu, Y.; Chen, Z.; Xu, Z.; Wang, T., Genomewide assessment of avocado germplasm determined from specific length amplified fragment sequencing and transcriptomes: population structure, genetic diversity, identification, and application of race-specific markers. Genes 2019, 10 (3), 215 , $10.3390 /$ genes 10030215 .

116. O’Brien, C.; Hiti-Bandaralage, J. C. H.; Hayward, A.; Mitter, N., Avocado (Persea americana Mill.). In Step Wise Protocols for Somatic Embryogenesis of Important Woody Plants, Jain, S. M., Gupta, P. K., Eds. Springer Cham, 2018 ; Vol. 85, pp 305-328, ISBN: 978-3-319-79086-2, doi:10.1007/978-3-319-79087-9_24.

117. Furnier, G.; Cummings, M.; Clegg, M., Evolution of the avocados as revealed by DNA restriction fragment variation. Journal of Heredity 1990, 81 (3), 183-188, doi:10.1093/oxfordjournals.jhered.a110963.

118. Chen, H.; Morrell, P. L.; Ashworth, V. E.; de La Cruz, M.; Clegg, M. T., Tracing the geographic origins of major avocado cultivars. Journal of Heredity 2009, 100 (1), 56-65, doi:10.1093/jhered/esn068.

119. Popenoe, W., The avocado - a horticultural problem. Trop Agric 1941, 18, 3-7.

120. Ayala-Silva, T.; Ledesma, N., Avocado history, biodiversity and production. In Sustainable Horticultural Systems, Nandwani, D., Ed. Springer: Cham, 2014; pp 157-205, ISBN:978-3-319-06903-6, doi:10.1007/978-3-319-06904-3_8.

121. Ben-Ya'acov, A.; Michelson, E., Avocado rootstocks. In Horticultural Reviews, Janick, J., Ed. John Wiley \& Sons Inc: New York, 1995; Vol. 17, pp 381-429, ISBN: 9780470650585.

122. Crane, J. H.; Balerdi, C. F.; Maguire, I., Avocado growing in the Florida home landscape. Hort. Sci. Dept., Florida Coop. Ext. Serv., Inst. Food Agr. Sci., Univ. Florida. Circular 2007, 1034, 1-12.

123. Krezdorn, A., Influence of rootstock on cold hardiness of avocados. Proc. Fla. State Hort. Soc, $1973 ; 86$ pp $346-$

348 .

124. Mickelbart, M. V.; Arpaia, M. L., Rootstock influences changes in ion concentrations, growth, and photosynthesis of 'Hass' avocado trees in response to salinity. Journal of the American Society for Horticultural Science 2002, 127 (4), 649655, doi:10.21273/jashs.127.4.649.

125. Barrientos-Priego, A. F., The importance of the conservation and evaluation of avocado genetic resources. In Proceedings of Avocado Brainstorming Session I. In Plant Breeding and Genetics, Arpaia, M. L. Eds., Hofshi Foundation: Riverside, 1999; pp 12-15.

126. Waring, R. H.; Running, S. W., Chapter 9 - The role of forests in global ecology. In Forest Ecosystems. Analaysis at Multiple Scales (Third Edition), Waring, R. H., Running, S. W., Eds. Academic Press: San Diego, 2007; pp 291-XXII, doi.org/10.1016/B978-012370605_8.50016-5.

127. Hiti-Bandaralage, J.; Hayward, A.; O’Brien, C.; Gleeson, M.; Nak, W.; Mitter, N., Advances in avocado propagation for the sustainable supply of planting materials. In Achieving Sustainable Cultivation of Tropical Fruits, Burleigh Dodds Science Publishing: Cambridge, United Kingdom, 2019; ISBN: 9781786762849, doi:1019103/as.2019.0054.19.

128. Barrientos-Priego, A. F.; López-López, L., Historia y genética del aguacate. Téliz, D. y Mora, A.(Comps.). El aguacate y su manejo integrado. $2^{a}($ Ed.) Ediciones Mundi-Prensa. DF México 2000, 19-31.

129. Lorea Hernández, F. G., La familia Lauraceae en el sur de México: diversidad, distribución y estado de conservación. Boletín de la Sociedad Botánica de México 2002, (71), doi:10.17129/botsci.1663.

130. Alcaraz, M.; Hormaza, J., Selection of potential pollinizers for 'Hass' avocado based on flowering time and malefemale overlapping. Scientia Horticulturae 2009, 121 (3), 267-271, doi:10.1016j.scienta.2009.02.001.

131. Vozzo, J. A., Tropical Tree Seed Manual U.S. Department of Agriculture, Forest Services: 2002. No. 721.

132. Folgado, R., Personal communication, The Huntington Library, Art Museum, and Botanical Gardens, San Marino CA, USA, 2020

133. Arpaia, M. L.; Focht, E., Personal communication, Department of Botany and Plant Sciences, University of California, Riverside, CA, USA, 2020.

134. Manosalva, P., Personal communication, Department of Microbiology and Plant Pathology, University of California, Riverside, CA, USA, 2020

135. Goenaga, R., Personal communication, USDA-ARS-Subtropical Horticulture Research Station, Miami, FL, USA,

2020.

136. Álvarez, S. P.; Quezada, G. Á.; Arbelo, O. C., Avocado (Persea americana Mill). Cultivos Tropicales 2015, 36 (2), 111-123, doi:10.13140/RG.2.2.19879.55200.

137. Barrientos-Priego, A., Personal communication, Departamento de Fitotecnia, Texcoco de Mora, Mexico, 2020

138. Nkansah, G.; Ofosu-Budu, K.; Ayarna, A., Avocado germplasm conservation and improvement in Ghana. In Proceedings of VII World Avocado Congress 2011, Cairns, Australia, 5-9 September; 2011.

139. Ben-Ya'acov, A.; Solis-Molin, A.; Bufler, G., The mountain avocado of Costa Rica Persea americana var. costarricense, a new subspecies. In Proceedings of the 5th world avocado congress. Granada, 2003; pp 19-24.

140. Alcaraz, M.; Hormaza, J., Molecular characterization and genetic diversity in an avocado collection of cultivars and local Spanish genotypes using SSRs. Hereditas 2007, 144 (6), 244-253, doi:10.1111/j.2007.0018-0661.02019x.

141. Dann, E., Personal Communication, Centre for Horticultural Science Queensland Alliance for Agriculture and Food Innovation, 2020.

142. Wiley, T., Personal communication, 2016.

143. Borokini, T. I., Conservation Science. International Journal of Conservation Science 2013, 4 (2), 197-212.

144. Cantuarias-Avilés, T., Personal communication, Department of Plant Production, University of Sao Paulo, Piracicaba SP, Brazil, 2020.

145. Jain, S. M.; Ishii, K., Micropropagation of Woody Plants and Fruits Kluwer Academic Publishers:Netherlands, 2003. Vol. 75. ISBN: 1-4020-1135-0. 
146. O’Brien, C.; Constantin, M.; Walia, A.; Yiing, J. L. Y.; Mitter, N., Cryopreservation of somatic embryos for avocado germplasm conservation. Scientia Horticulturae 2016, 211, 328-335, doi.org/10.1016/j.scienta.2016.09.008.

147. Pliego-Alfaro, F.; Murashige, T., Somatic embryogenesis in avocado (Persea americana Mill.) in vitro. Plant cell, tissue and organ culture 1988, 12 (1), 61-66.

148. Raharjo, S.; Litz, R. E., Rescue of genetically transformed avocado by micrografting. Proceedings V World Avocado Congress (Actas V Congreso Mundial del Aguacate), 2003; pp 119-122.

149. Witjaksono, Y.; Litz, R., Maturation and germination of avocado (Persea americana Mill.) somatic embryos. Plant Cell Tissue Organ Cult 1999, 58, 141-148.

150. Encina, C. L.; Parisi, A.; O’Brien, C.; Mitter, N., Enhancing somatic embryogenesis in avocado (Persea americana Mill.) using a two-step culture system and including glutamine in the culture medium. Scientia Horticulturae 2014, 165, 4450, doi:org/10.1016/j.scienta.2013.10.019.

151. Efendi, D.; Litz, R. E., Cryopreservation of avocado. In Proceedings of V Congreso Mundial del Aguacate, Actas: Consejería de Agricultura y Pesca, Junta de Andalucía. Sevilla, España, 2003; 1 pp 111-114.

152. Vargas, V. M. Efecto fisiológico de brasinoesteroides y crioprotectores sobre yemas axilares de aguacate criollo producidas in vitro. 2008.

153. Vidales-Fernandez, I.; Larios-Guzman, A.; Tapia-Vargas, L. M.; Guillen-Andrade, H.; Villasenor-Ramirez, F., Criopreservación de germoplasma de aguacate. In Proceedings of VII World Avocado Congress, Cairns, Australia, 2011.

154. Preece, J.; Compton, M., Problems with explant exudation in micropropagation. In High-Tech and Micropropagation I. Biotechnology in Agriculture and Forestry, Bajaj, Y. P. S., Ed. Springer: Berlin, 1991; Vol. 17, pp 168189, ISBN: 978-3-642-76417-2, doi:10.1007/978-3-642-76415-8_10.

155. González-Benito, M. E.; Kremer, C.; Ibáñez, M. A.; Martín, C., Effect of antioxidants on the genetic stability of cryopreserved mint shoot tips by encapsulation-dehydration. Plant Cell, Tissue and Organ Culture (PCTOC) 2016, 127 (2), 359-368, 10.1007/s11240-016-1056-8.

156. Halliwell, B.; Gutteridge, J. M., Free Radicals in Biology and Medicine Oxford University Press, USA: 2015.

157. Fleck, R. A.; Benson, E. E.; Bremner, D. H.; Day, J. G., Studies of free radical-mediated cryoinjury in the unicellular green alga Euglena gracilis using a non-destructive hydroxyl radical assay: a novel approach for developing protistan cryopreservation strategies. Free Radical Research 2000, 32 (2), 157-170, doi:10.1080/10715760000300161.

158. Obert, B.; Benson, E. E.; Millam, S.; Pret'ová, A.; Bremner, D. H., Moderation of morphogenetic and oxidative stress responses in flax in vitro cultures by hydroxynonenal and desferrioxamine. Journal of Plant Physiology 2005, 162 (5), 537-547, doi:10.1016j.jplph.2004.06.002.

159. Johnston, J. W.; Harding, K.; Benson, E. E., Antioxidant status and genotypic tolerance of Ribes in vitro cultures to cryopreservation. Plant Science 2007, 172 (3), 524-534, doi:10.1016/j.plantsci.2006.11.001.

160. Reed, B. M., 4. Are antioxidants a magic bullet for reducing oxidative stress during cryopreservation? 2012 ; Vol. 65, pp 340-340, doi:10.1016/j.cryobiol.2012.07.005.

161. Uchendu, E. E.; Leonard, S. W.; Traber, M. G.; Reed, B. M., Vitamins C and E improve regrowth and reduce lipid peroxidation of blackberry shoot tips following cryopreservation. Plant Cell Reports 2010, 29 (1), 25, doi:10.1007/s00299009-0795-y.

162. Wang, Q.; Laamanen, J.; Uosukainen, M.; Valkonen, J., Cryopreservation of in vitro-grown shoot tips of raspberry (Rubus idaeus L.) by encapsulation-vitrification and encapsulation-dehydration. Plant Cell Reports 2005, 24 (5), 280-288, doi:10.1007/s00299-005-0936-x.

163. Shao, H.-B.; Chu, L.-Y.; Lu, Z.-H.; Kang, C.-M., Primary antioxidant free radical scavenging and redox signaling pathways in higher plant cells. International Journal of Biological Sciences 2007, 4 (1), 8, doi:10.7150/ijbs.4.8.

164. Smirnoff, N.; Wheeler, G. L., Ascorbic acid in plants: biosynthesis and function. Critical Reviews in Plant Sciences 2000, 19 (4), 267-290, doi:10.1080/07352680091139231.

165. Fretz, A.; Lörz, H., Cryopreservation of in vitro cultures of barley (Hordeum vulgare L. and H. murinum L.) and transgenic cells of wheat (Triticum aestivum L.). Journal of Plant Physiology 1995, 146 (4), 489-496, doi:10.1016/s01761617(11)82013-4.

166. Chang, Y.; Reed, B. M., Pre-culture conditions influence cold hardiness and regrowth of Pyrus cordata shoot tips after cryopreservation. HortScience 2001, 36 (7), 1329-1333, doi:10.21273/hortsci.36.7.1329.

167. Ashmore, S. E.; Drew, R. A.; Azimi, M., Vitrification-based shoot tip cryopreservation of Carica papaya and a wild relative Vasconcellea pubescens. Australian Journal of Botany 2007, 55 (5), 541-547, doi:10.1071/BT06144.

168. Gonzalez-Arnao, M. T.; Martinez-Montero, M. E.; Cruz-Cruz, C. A.; Engelmann, F., Advances in cryogenic techniques for the long-term preservation of plant biodiversity. In Biotechnology and Biodiversity, Ahuja, M., Ramawat, K., Eds. Springer: Cham, 2014; pp 129-170, ISBN: 978-3-319-09380-2, doi:10.1007/978-3-319-09381-9_8.

169. Janská, A.; Maršík, P.; Zelenková, S.; Ovesná, J., Cold stress and acclimation - what is important for metabolic adjustment? Plant Biology 2010, 12, 395-405, doi:10.1111/j.1438-8677.2009.00299.x.

170. Arora, R., Freezing tolerance and cold acclimation in plants. 2010, doi:10.1036/1097-8542. Yb100044.

171. Gusta, L.; Trischuk, R.; Weiser, C. J., Plant cold acclimation: The role of abscisic acid. Journal of Plant Growth Regulatation 2005, 24 (4), 308-318, doi:10.1007/s00344-005-0079-x.

172. Reed, B., Pre-treatment strategies for cryopreservation of plant tissues. In In Vitro Conservation of Plant Genetic Resources, Normah, M. N., Narimah, M. K., Clyde, M. M. Eds., Universiti Kebangsaan: Malaysia, 1996; pp 73-87.

173. Janmohammadi, M.; Zolla, L.; Rinalducci, S., Low temperature tolerance in plants: changes at the protein level. Phytochemistry 2015, 117, 76-89, doi:10.1016/j.phytochem.2015.06.003.

174. Fki, L.; Bouaziz, N.; Chkir, O.; Benjemaa-Masmoudi, R.; Rival, A.; Swennen, R.; Drira, N.; Panis, B., Cold hardening and sucrose treatment improve cryopreservation of date palm meristems. Biologia Plantarum 2013, 57 (2), 375 379, doi:10.1007/s10535-012-0284-y. 
175. Reed, B. M., Responses to ABA and cold acclimation are genotype dependent for cryopreserved blackberry and raspberry meristems. Cryobiology 1993, 30 (2), 179-184, doi:10.1006/cryo.1993.1017.

176. Kaviani, B., Conservation of plant genetic resources by cryopreservation. Australian Journal of Crop Science 2011, 5 (6), 778.

177. Vandenbussche, B.; Leurdian, S.; Verdoodt, V.; Gysemberg, M.; de Proft, M., Changes in sugar content and fatty acid composition of in vitro sugar beet shoots after cold acclimation: influence on survival after cryopreservation. Plant Growth Regulation 1999, 28 (3), 157-163, doi:10.1023/a:1006262827160.

178. Nishida, I.; Swinhoe, R.; Slabas, A. R.; Murata, N., Cloning of Brassica napus CTP: phosphocholine cytidylyltransferase cDNAs by complementation in a yeast cct mutant. Plant Molecular Biology 1996, 31 (2), 205-211, doi:10.1007/BF00021784.

179. Raison, J. K., The influence of temperature-induced phase changes on the kinetics of respiratory and other membrane-associated enzyme systems. In Membrane Structure and Mechanisms of Biological Energy Transduction, Avery, J., Ed. Springer: Boston, MA, 1972; pp 559-583, ISBN: 978-1-4684-2018-0, doi:10.1007/978-1-4684-2016-6_30.

180. Cossins, A. R., Temperature adaptation of biological membranes : In Proceedings of the meeting held in Cambridge under the auspices of the Society for Experimental Biology in conjunction with its US/Canadian counterparts. Portland Press: London, Chapel Hill, NC, 1994; ISBN: 1855780623.

181. Irving, R.; Lanphear, F., Environmental control of cold hardiness in woody plants. Plant Physiology 1967, 42 (9), 1191-1196, doi:10.1104/pp.42.9.1191.

182. van Huystee, R. B.; Weiser, C.; Li, P., Cold acclimation in Cornus stolonifera under natural and controlled photoperiod and temperature. Botanical Gazette 1967, 128 (3/4), 200-205, doi:10.1086336399.

183. Borovskii, G. B.; Stupnikova, I. V.; Antipina, A. I.; Downs, C. A.; Voinikov, V. K., Accumulation of dehydrin-likeproteins in the mitochondria of cold-treated plants. Journal of Plant Physiology 2000, 156 (5), 797-800, doi.org/10.1016/S0176-1617(00)80250-3.

184. Danyluk, J.; Perron, A.; Houde, M.; Limin, A.; Fowler, B.; Benhamou, N.; Sarhan, F., Accumulation of an acidic dehydrin in the vicinity of the plasma membrane during cold acclimation of wheat. The Plant Cell 1998, 10 (4), 623-638, doi:10.1105/tpc.10.4.623.

185. Coelho, N.; González-Benito, M. E.; Martín, C.; Romano, A., Cryopreservation of Thymus lotocephalus shoot tips and assessment of genetic stability. CryoLetters 2014, 35 (2), 119-128.

186. Park, S. U.; Kim, H. H., Cryopreservation of sweet potato shoot tips using a droplet-vitrification procedure. CryoLetters 2015, 36 (5), 344-52.

187. Ashmore, S. E.; Azimi, M.; Drew, R. A., Cryopreservation trials in Carica papaya. ActaHortic. ActaHortic: 2001; Vol. 560, pp 117-120, 10.17660/ActaHortic.2001.560.16.

188. López-López, L.; Barrientos-Priego, A.; Ben-Ya'acov, A., Variabilidad genética de los bancos de germoplasma de aguacate preservados en el Estado de México. Revista Chapingo Serie Horticultura 1999, 5, 19-23.

189. Mikuła, A., Comparison of three techniques for cryopreservation and reestablishment of long-term Gentiana tibetica suspension culture. CryoLetters 2006, 27 (5), 269-282.

190. Mikuła, A.; Tykarska, T.; Kuraś, M., Ultrastructure of Gentiana tibetica proembryogenic cells before and after cooling treatments. CryoLetters 2005, 26 (6), 367-378.

191. Pritchard, H.; Grout, B.; Short, K., Osmotic stress as a pregrowth procedure for cryopreservation: 1. Growth and ultrastructure of sycamore and soybean cell suspensions. Annals of Botany 1986, 57 (1), 41-48, doi:10.1093/oxfordjournals.aob.ao87092.

192. Panis, B.; Strosse, H.; van den Hende, S.; Swennen, R., Sucrose pre-culture to simplify cryopreservation of banana meristem cultures. CryoLetters 2002, 23 (6), 375-384.

193. Lynch, P. T.; Siddika, A.; Johnston, J. W.; Trigwell, S. M.; Mehra, A.; Benelli, C.; Lambardi, M.; Benson, E. E., Effects of osmotic pre-treatments on oxidative stress, antioxidant profiles and cryopreservation of olive somatic embryos. Plant Science 2011, 181 (1), 47-56, doi:10.1016j.plantsci.2011.03.009.

194. Göldner, E. M.; Seitz, U.; Reinhard, E., Cryopreservation of Digitalis lanata Ehrh. cell cultures: Pre-culture and freeze tolerance. Plant Cell, Tissue and Organ Culture 1991, 24 (1), 19-24, doi:10.1007/bf00044260.

195. Malabadi, R. B.; Nataraja, K., Cryopreservation and plant regeneration via somatic embryogenesis using shoot apical domes of mature Pinus roxburghii sarg, trees. In Vitro Cellular \& Developmental Biology - Plant 2006, 42 (2), 152 , doi:10.1079/ivp2005731.

196. Crowe, L. M., Lessons from nature: the role of sugars in anhydrobiosis. Comparative Biochemistry and Physiology Part A: Molecular \& Integrative Physiology 2002, 131 (3), 505-513, doi.org/10.1016/S1095-6433(01)00503-7.

197. Antony, J. J. J.; Keng, C. L.; Mahmood, M.; Subramaniam, S., Effects of ascorbic acid on PVS2 cryopreservation of Dendrobium Bobby Messina's PLBs supported with SEM analysis. Applied Biochemistry and Biotechnology 2013, 171 (2), 315-329, doi:10.1007s12010-013-0369-x.

198. Hirsh, A. G., Vitrification in plants as a natural form of cryoprotection. Cryobiology 1987, 24 (3), 214-228, doi:10.1016/0011-2240(87)90024-1.

199. Herbert, R.; Vilhar, B.; Evett, C.; Orchard, C.; Rogers, H.; Davies, M.; Francis, D., Ethylene induces cell death at particular phases of the cell cycle in the tobacco TBY-2 cell line. Journal of Experimental Botany 2001, 52 (361), 1615-1623, doi:10.1093/jexbot/52.361.1615.

200. Williams, W. P.; Quinn, P. J.; Tsonev, L. I.; Koynova, R. D., The effects of glycerol on the phase behaviour of hydrated distearoylphosphatidylethanolamine and its possible relation to the mode of action of cryoprotectants. Biochimica et Biophysica Acta (BBA)-Biomembranes 1991, 1062 (2), 123-132, doi:10.1016/0005-2736(91)90383-j.

201. Burritt, D. J., Proline and the cryopreservation of plant tissues: functions and practical applications. In Current Frontiers in Cryopreservation, Katkov, I. I., Ed. InTech: 2012. 
202. Cleland, D.; Krader, P.; McCree, C.; Tang, J.; Emerson, D., Glycine betaine as a cryoprotectant for prokaryotes. Journal of Microbiological Methods 2004, 58 (1), 31-38, doi:10.1016/j.mimet.2004.02.015.

203. Folgado, R.; Panis, B.; Sergeant, K.; Renaut, J.; Swennen, R.; Hausman, J.-F., Unravelling the effect of sucrose and cold pretreatment on cryopreservation of potato through sugar analysis and proteomics. Cryobiology 2015, 71 (3), 432-441, doi:10.1016j.cryobiol.2015.09.006.

204. Chang, Y.; Reed, B. M., Extended alternating-temperature cold acclimation and culture duration improve pear shoot cryopreservation. Cryobiology 2000, 40 (4), 311-322, doi:10.1006/cryo.2000.2251.

205. Imanishi, H. T.; Suzuki, T.; Masuda, K.; Harada, T., Accumulation of raffinose and stachyose in shoot apices of Lonicera caerulea L. during cold acclimation. Scientia Horticulturae 1998, 72 (3-4), 255-263, doi:10.1016/s03044238(97)00129-5.

206. Reed, B. M.; Okut, N.; d'Achino, J.; Narver, L.; deNoma, J., Cold storage and cryopreservation of hops (Humulus L.) shoot cultures through application of standard protocols. CryoLetters 2003, 24 (6), 389-396.

207. O'Brien, C.; Hiti-Bandaralage, J.; Folgado, R.; Lahmeyer, S.; Hayward, A.; Folsom, J.; Mitter, N., A method to increase regrowth of vitrified shoot tips of avocado (Persea americana Mill.): First critical step in developing a cryopreservation protocol. Scientia Horticulturae 2020, 266, 109305, doi.org/10.1016/j.scienta.2020.109305.

208. O’Brien, C.; Hiti-Bandaralage, J. C.; Folgado, R.; Lahmeyer, S.; Hayward, A.; Mitter, N., Developing a cryopreservation protocol for avocado (Persea americana Mill.) shoot tips. Cryobiology 2018, 85, 171, doi:10.1016/j.cryobiol.2018.10.199.

209. O’Brien, C.; Hiti-Bandaralage, J. C. A.; Folgado, R.; Lahmeyer, S.; Hayward, A.; Folsom, J.; Mitter, N., First report on cryopreservation of mature shoot tips of two avocado (Persea americana Mill.) rootstocks. Plant Cell, Tissue and Organ Culture (PCTOC) 2020, doi:10.1007/s11240-020-01861-y.

210. Mittler, R., Oxidative stress, antioxidants and stress tolerance. Trends in Plant Science 2002, 7 (9), 405-410, doi:10.1016/S1360-1385(02)02312-9. 